
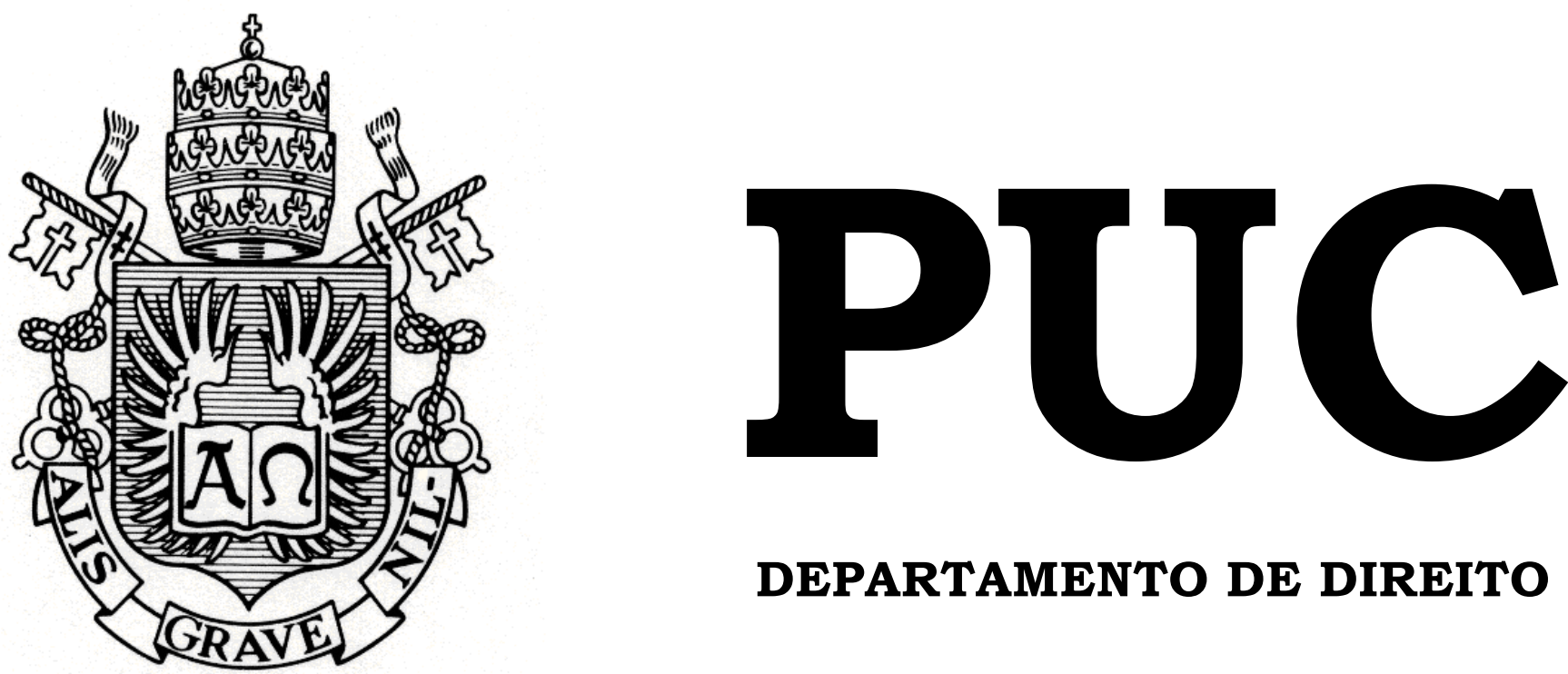

DEPARTAMENTO DE DIREITO

\title{
SUFRÁGIO FEMININO E DEMOCRACIA NO BRASIL
}

por

LUIZA CHAVES SANTOS

ORIENTADORA: Thula Pires

2017.2

PONTIFÍCIA UNIVERSIDADE CATÓLICA DO RIO DE JANEIRO

RUA MARQUÊS DE SÃO VICENTE, 225 - CEP 22453-900

$$
\text { RIO DE JANEIRO - BRASIL }
$$




\section{SUFRÁGIO FEMININO E DEMOCRACIA NO BRASIL}

por

\section{LUIZA CHAVES SANTOS}

Monografia apresentada ao Departamento de Direito da Pontificia Universidade Católica do Rio de Janeiro (PUC-Rio) para a obtenção do Título de Bacharel em Direito.

Orientadora: Thula Pires 


\section{AGRADECIMENTOS}

Aos meus pais, Angela e Bernardo, pelo amor e apoio incondicionais em todos os momentos da minha vida, e por serem os grandes responsáveis pela minha paixão pelo estudo e pelos livros.

Ao meu avô Wanderley, pelos ensinamentos e conversas durante a elaboração deste trabalho, pela indicação bibliográfica e por tudo que ainda tenho a aprender com ele.

Aos meus tios Fabito e Cris, por sempre estarem disponíveis para me ajudar, seja com este trabalho ou não, e por toda a atenção e carinho desde que me entendo por gente.

Ao meu irmão André, pela amizade e pelos momentos de descontração, especialmente na reta final.

A toda a minha família, por me fazerem sentir a pessoa mais amada e querida do mundo e por toda a confiança em mim.

Aos meus amigos, por estarem comigo sempre que precisei.

À minha orientadora Thula, pela dedicação e atenção, por todas as longas e divertidas conversas e por trazer um ponto de vista que enriqueceu e ampliou a minha visão sobre o tema. 


\section{RESUMO}

SANTOS, Luiza Chaves. Sufrágio Feminino e Democracia no Brasil. Rio de Janeiro. 2017. 80 p. Monografia de final de curso. Departamento de Direito da Pontifícia Universidade Católica do Rio de Janeiro - PUC-Rio.

O sufrágio universal é essencial para a plenitude da democracia representativa, na medida em que é por meio deste que a soberania popular é exercida. $\mathrm{O}$ voto é o que legitima o exercício do poder pelos governantes. Por isso, é fundamental que todos aqueles submetidos às decisões tomadas pelos governantes tenham voz no processo de escolha de seus representantes. As democracias implementadas após as revoluções liberais pregavam o sufrágio universal, que, no entanto, era aplicável somente a poucos homens brancos. Foram necessárias décadas de lutas e articulações para que, aos poucos, as barreiras impostas ao direito ao sufrágio (etnia, renda, sexo) fossem sendo quebradas. Nesse contexto, este trabalho tem o objetivo de compreender a luta pelo sufrágio feminino no Brasil, levando em conta os aspectos históricos, sociais e legais desse processo, bem como contextualizando o movimento brasileiro em relação à luta sufragista de outros países.

PALAVRAS-CHAVE: Democracia. Sufrágio universal. Direitos políticos. Feminismo. Movimentos sufragistas. Voto feminino. 


\section{SUMÁRIO}

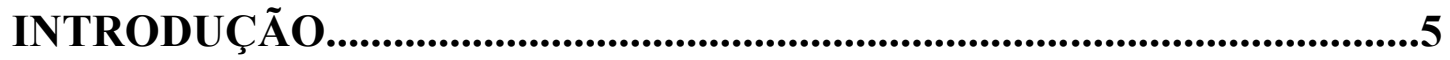

CAPÍTULO I - DEMOCRACIA REPRESENTATIVA E SUFRÁGIO

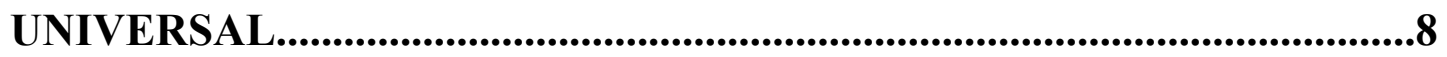

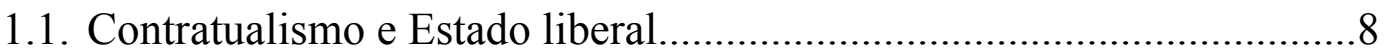

1.2. Democracia, cidadania, sufrágio e voto...............................................14

CAPÍTULO II - CONTEXTO MUNDIAL: A EXPERIÊNCIA SUFRAGISTA NA INGLATERRA, NOS ESTADOS UNIDOS E NA

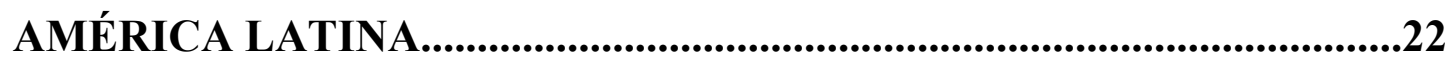

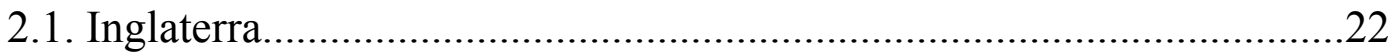

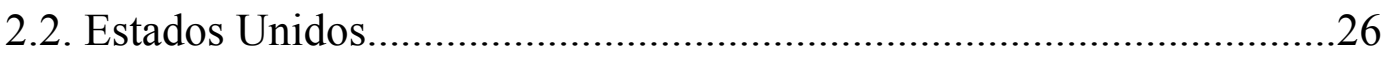

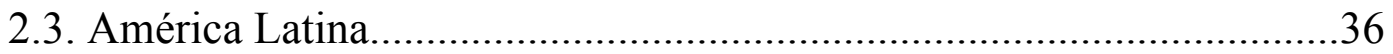

CAPÍTULO III - A CONQUISTA DO SUFRÁGIO FEMININO NO

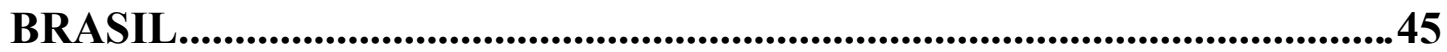

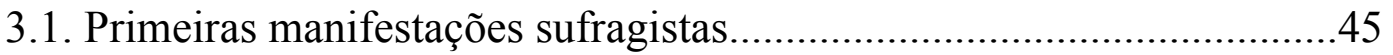

3.2. Assembleia Constituinte e Constituição de 1891 .....................................47

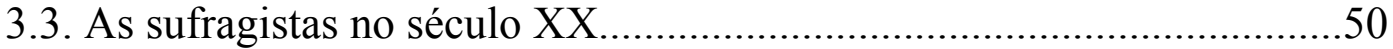

3.4. Legislação infraconstitucional e algumas decisões

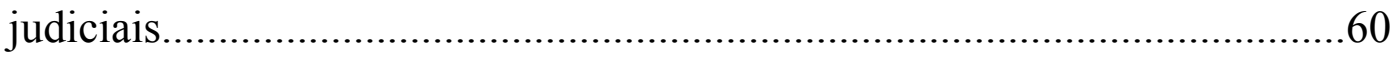

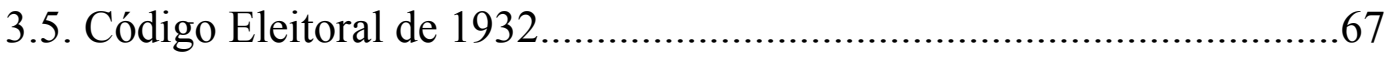

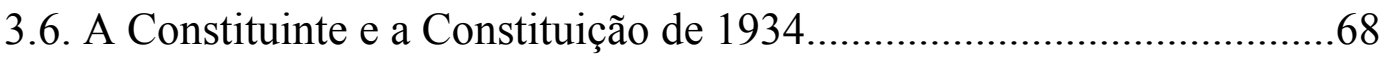

3.7. Algumas considerações sobre o movimento sufragista brasileiro. 70

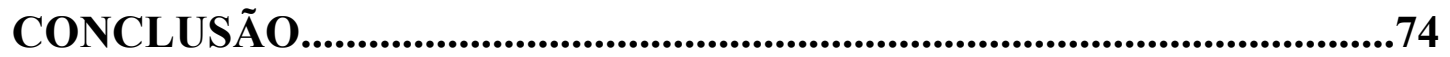

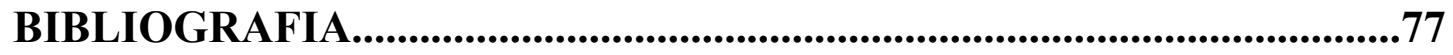




\section{INTRODUÇÃO}

Atualmente, temos uma Constituição que estabelece categoricamente que “a soberania popular será exercida pelo sufrágio universal e pelo voto direto e secreto, com valor igual para todos (...)", sintetizando nessas poucas palavras o princípio basilar da democracia representativa, segundo o qual a titularidade de todo poder é do povo, que o exercerá por meio de representantes eleitos através do voto. Além disso, o referido artigo consagra expressamente a igualdade de valor do voto para "todos" - termo que, hoje, indubitavelmente inclui homens e mulheres.

No entanto, nem sempre foi assim; durante décadas as mulheres foram excluídas da categoria de eleitoras, sendo o sufrágio "universal" aplicável somente a determinados homens. $\mathrm{O}$ voto feminino só veio a ser assegurado na legislação infraconstitucional brasileira no Código Eleitoral de 1932, sendo pela primeira vez reconhecido, em âmbito constitucional, na Constituição de 1934, que estabelecia como eleitores "os brasileiros de um e de outro sexo, maiores de 18 anos".2

Para que os direitos políticos fossem estendidos às mulheres, foram necessárias décadas de lutas, articulações feministas e intensos debates políticos. Este trabalho pretende estudar como se deu o processo de conquista do sufrágio feminino no Brasil, desde as primeiras manifestações de mulheres no século XIX até a vitória na década de 1930.

Faz-se imperioso, inicialmente, analisar a importância do sufrágio universal como expressão da democracia representativa. Dessa forma, no

\footnotetext{
1 Artigo 14 da Constituição da República Federativa do Brasil de 1988. Disponível em < http://www.planalto.gov.br/ccivil_03/constituicao/constituicaocompilado.htm>. Acesso em 3 de novembro de 2017.

${ }^{2}$ Artigo 108 da Constituição da República dos Estados Unidos do Brasil de 16 de julho de 1934. Disponível em <http://www.planalto.gov.br/ccivil_03/constituicao/constituicao34.htm>. Acesso em 12 de outubro de 2017.
} 
primeiro capítulo deste trabalho serão discutidos alguns conceitos fundamentais, como democracia, cidadania, sufrágio e voto, buscando evidenciar que o sufrágio universal é indispensável para a plenitude do regime democrático. É o sufrágio que legitima o exercício do poder em uma democracia representativa. Isso porque é através do voto que os indivíduos intervêm no processo decisório, elegendo aqueles que irão representá-los nas funções governamentais.

Não é à toa que, como será visto neste estudo, as sufragistas de diversos países do mundo reconheciam no voto um instrumento para conquistar e assegurar outros direitos, não sendo um fim em si mesmo. $\mathrm{O}$ voto, em um regime democrático, é a maneira de intervir no processo político de tomada de decisão e ser ouvido pelos governantes.

No segundo capítulo, será apresentado sucintamente um panorama da conquista do sufrágio feminino em outros países, quais sejam: Inglaterra, Estados Unidos, Argentina, México, Panamá, Colômbia, Chile, Uruguai e Equador, de modo a compreender os movimentos sufragistas que influenciaram ou dialogaram com o brasileiro, bem como a contextualizar a luta que ocorria no Brasil frente a outros países. É importante destacar que não se trata de um trabalho de direito comparado; a exposição acerca dos movimentos sufragistas de tais países visa a fornecer mais elementos para uma melhor compreensão e contextualização do movimento brasileiro, mas não será realizado um efetivo exercício de comparação.

Por fim, o terceiro capítulo desenvolverá de maneira mais detalhada a conquista do voto feminino no Brasil, levando em conta os aspectos históricos, sociais e legais desse processo. Serão abordadas as primeiras manifestações, já no século XIX, de brasileiras consideradas pioneiras na defesa de direitos femininos; as discussões travadas na Assembleia Constituinte de 1891, em que a questão do voto feminino foi suscitada e intensamente debatida; as 
organizações sufragistas formadas no século XX; os avanços na legislação infraconstitucional até o Código Eleitoral de 1932, que estendeu nacionalmente o direito ao voto às mulheres; e a constitucionalização do sufrágio feminino na Constituição de 1934, que confirmou a vitória de 1932, embora tenha estabelecido que o voto feminino seria facultativo, enquanto o masculino era obrigatório.

Ao final, serão tecidas algumas considerações críticas a respeito do movimento sufragista brasileiro e do resultado prático da conquista do voto feminino. Tal movimento, de caráter mais elitista, não propunha uma ruptura com a ordem social vigente, isto é, não pretendia operar alterações sociais significativas, talvez porque isso não interessasse às classes mais elevadas. Assim, a conquista do sufrágio não significou efetivamente uma emancipação política plena das mulheres, visto que muitas continuaram excluídas do processo eleitoral via analfabetismo. O direito de votar somente foi estendido aos analfabetos em 1985, e até os dias de hoje não lhes foi permitido o direito de serem votados.

Apesar disso, a conquista do sufrágio feminino na década de 1930 foi um grande avanço rumo à igualdade de direitos políticos para mulheres no Brasil, motivo pelo qual faz-se muito importante o estudo do movimento sufragista brasileiro.

A metodologia empregada é a de pesquisa bibliográfica e os dados secundários, retirados da literatura utilizada. Tendo em vista a necessária interdisciplinaridade do tema escolhido, que envolve tanto a análise histórica do movimento sufragista feminino quanto o aporte teórico relativo aos fundamentos da democracia representativa e ao sufrágio universal, a bibliografia será focada em autores de diferentes áreas do conhecimento, notadamente História, Teoria Política e Direito (especialmente autores constitucionalistas). 


\section{DEMOCRACIA REPRESENTATIVA E SUFRÁGIO UNIVERSAL}

\subsection{CONTRATUALISMO E ESTADO LIBERAL}

Para entender a importância da conquista de direitos políticos pelas mulheres, faz-se mister abordar, ainda que brevemente, alguns conceitos fundamentais como "democracia representativa", "cidadania", "direitos políticos", "sufrágio" e "voto". Não se pretende esgotar todas as discussões a respeito de tais conceitos, mas apenas tentar estabelecer uma relação entre os termos de modo a evidenciar que o direito ao sufrágio é peça essencial da democracia moderna.

Ao se falar em democracia moderna, contudo, não se pode deixar de mencionar o contrato social. Embora a doutrina contratualista não signifique, necessariamente, uma defesa do regime democrático (como exemplo, podemos citar Thomas Hobbes, que defendia o Estado Absoluto), o contratualismo foi, nas palavras de Norberto Bobbio, "um dos momentos decisivos para a fundação da teoria moderna da democracia"”. Segundo Bobbio,

A teoria da soberania popular e a teoria do contrato social estão estreitamente ligadas, por duas razões, pelo menos: o populus concebido como universitas civium é ele mesmo, na sua origem, o produto de um acordo (o chamado pactum societatis); uma vez constituído o povo, a instituição do Governo, quaisquer que sejam as modalidades da transmissão do poder, total ou parcial, definitivo ou temporário, irrevogável ou revogável, acontece na forma própria de contrato (o chamado pactum subjectionis). ${ }^{4}$

O contratualismo, que dominou a teoria política nos séculos XVII e XVIII, compreende, de maneira geral, as teorias que veem a origem da sociedade e o fundamento do poder político num contrato, num acordo entre os

\footnotetext{
${ }^{3}$ BOBBIO Norberto; MATTEUCCI Nicola; PASQUINO Gianfranco. Dicionário de política. Trad. de Carmen C, Varriale et. al.; coord. trad. João Ferreira; rev. geral João Ferreira e Luis Guerreiro Pinto Cacais. 11 a ed. Brasília: Editora Universidade de Brasília, 1998. p. 322.

${ }^{4}$ BOBBIO Norberto; MATTEUCCI Nicola; PASQUINO Gianfranco. Dicionário de política. p. 322.
} 
indivíduos que assinalaria o fim do estado de natureza e o início do estado social e político. ${ }^{5}$ No pensamento liberal, o contrato social é um instrumento que formaliza a igualdade civil ${ }^{6}$, por meio do qual o Estado é estabelecido com base em um ato racional de vontade dos indivíduos.

No entanto, o contrato social pode ser encarado como uma história de dominação, conforme apontou a teórica política inglesa Carole Pateman em seu livro O Contrato Sexual ${ }^{7}$. Nas palavras de Pateman, “a teoria do contrato social convencionalmente é apresentada como uma história sobre a liberdade"8, segundo a qual os homens teriam trocado uma situação de insegurança e instabilidade (estado de natureza) pela liberdade civil e equitativa, que seria assegurada pelo Estado. Por outro lado, o que Pateman chama de contrato sexual é uma "história de sujeição". Para a autora, o contrato original cria, ao mesmo tempo, a liberdade (do homem) e a dominação (da mulher). $\mathrm{O}$ direito patriarcal dos homens sobre as mulheres é criado pelo contrato sexual, mas é encarado como irrelevante do ponto de vista político, por fazer parte da vida privada.

Ainda de acordo com Pateman, as teorias do contrato social geralmente ignoram o fato de que as mulheres estão excluídas dele. O contrato é feito por homens. Pateman aponta uma contradição na própria gênese do contrato social: ele pressupõe a liberdade e igualdade de todos homens no estado de natureza, as quais, por meio de um acordo, seriam trocadas pela segurança e liberdade civil através da instituição do Estado. Porém, as mulheres não nascem livres, não têm a liberdade natural. Portanto, somente os homens poderiam celebrar e

\footnotetext{
${ }^{5}$ BOBBIO Norberto; MATTEUCCI Nicola; PASQUINO Gianfranco. Dicionário de politica. p. 272.

${ }^{6}$ MIGUEL, Luis Felipe. Carole Pateman e a crítica feminista do contrato. Revista Brasileira de Ciências Sociais, v. 32, n. 93, 2017. Disponível em < http://www.scielo.br/pdf/rbcsoc/v32n93/01026909-rbcsoc-3293032017.pdf>. Acesso em 27 de outubro de 2017.

${ }^{7}$ PATEMAN, Carole. O Contrato Sexual. Tradução de Marta Avancini. Rio de Janeiro: Paz e Terra, 1993.

${ }^{8}$ PATEMAN, Carole. O Contrato Sexual. p. 16.

${ }^{9}$ PATEMAN, Carole. O Contrato Sexual. p. 16.
} 
participar do contrato, enquanto as mulheres seriam meramente objeto do contrato. ${ }^{10}$

Dessa forma, é possível concluir que o contrato social, teoria utilizada para explicar a origem do Estado e legitimar a sua existência, já é por si uma história de exclusão de gênero. A sujeição da mulher existiria desde o surgimento do Estado, criado por homens e para homens. Vale notar que o filósofo Charles Mills, inspirado nas críticas de Pateman, escreveu o livro $O$ Contrato Racial ${ }^{11}$, em que também revisita a tradição política baseada no contrato social para explicar que este trouxe consigo a subordinação racial.

Com base nas ideias de Pateman e de Mills, é possível identificar, no modelo de Estado forjado após as revoluções liberais, no final do século XVIII, uma história de liberdade e de exclusão. Essas revoluções implementaram em países ocidentais a democracia representativa, sob o ideal de que, através da representação, seria possível construir uma forma de governo permitindo a participação de todo o povo, de modo a preservar a soberania popular. ${ }^{12} \mathrm{~A}$ participação de todos os cidadãos seria garantida por meio do sufrágio universal. Entretanto, esse sufrágio dito "universal" era permitido apenas a poucos homens brancos. Durante mais de um século após as referidas revoluções, diversas barreiras eram impostas ao direito ao sufrágio, tais como raça, sexo, renda e nível de instrução.

Fábio Konder Comparato ${ }^{13}$ considera que a Declaração de Independência dos Estados Unidos, de 1776, foi o primeiro documento, na história política moderna, a estabelecer os princípios democráticos. A Declaração reconhece a soberania popular como princípio fundamental do Estado que se firmava

\footnotetext{
${ }^{10}$ PATEMAN, Carole. O Contrato Sexual.p. 21.

${ }^{11}$ MILLS, Charles W. The racial contract. Ithaca, NY: Cornell University Press, 1997. Apud MILLS, Charles W. O Contrato de dominação. Meritum, revista de Direito da Universidade FUMEC, v. 8, n. $2,2013$.

${ }^{12}$ FERREIRA FILHO, Manoel Gonçalves. Curso de Direito Constitucional. p. 71.

${ }^{13}$ COMPARATO, Fábio Konder. A afirmação histórica dos Direitos Humanos. 6 ed. São Paulo: Saraiva, 2008. pp. 101 e 102.
} 
independente, e identificava a existência de direitos inerentes a todo ser humano, como a vida e a liberdade. Segundo Comparato, a independência dos Estados Unidos representou o ato inaugural da democracia moderna, que combinou, sob regime constitucional, a representação popular com a limitação de poderes governamentais. ${ }^{14}$

Contudo, o Congresso de 1776 rejeitou parte do texto original de Thomas Jefferson, notadamente o trecho em que se condenava o tráfico negreiro. ${ }^{15} \mathrm{~A}$ abolição da escravidão só veio a ocorrer, nos Estados Unidos, em 1863, quase 100 anos após a independência norte-americana. Ou seja, ainda que a Declaração de Independência reconhecesse direitos inalienáveis de "todos" os homens, na verdade, um quinto da população à época da revolução não tinha esses direitos assegurados.

As barreiras ao sufrágio universal foram sendo derrubadas ao longo de mais de um século após a revolução americana. O direito ao voto dos homens negros só foi assegurado em 1870, com a $15^{\mathrm{a}}$ emenda à Constituição; o sufrágio feminino somente em 1920, com a $19^{\mathrm{a}}$ emenda; e a redução da idade do voto para dezoito anos só ocorreu em $1971 .{ }^{16}$ É importante notar que, ainda que a vedação à restrição do sufrágio por motivos de raça ou cor tenha ocorrido em 1870, os Estados segregacionistas contornavam essa proibição com a instituição de um "imposto eleitoral", em valor que os homens negros, em geral, não podiam pagar. Somente em 1964, com a $24^{\text {a }}$ emenda constitucional, é que se estabeleceu que nenhum Estado poderia cercear o direito dos cidadãos ao sufrágio devido à falta de pagamento de qualquer

\footnotetext{
${ }^{14}$ COMPARATO, Fábio Konder. A afirmação histórica dos Direitos Humanos. p. 95.

${ }^{15}$ COMPARATO, Fábio Konder. A afirmação histórica dos Direitos Humanos. p. 101.

${ }^{16}$ CROWLEY, John. $O$ voto secreto contra a democracia americana (1880-1910). In: CANÊDO, Letícia Bicalho (org.). Sufrágio universal e a invenção democrática. São Paulo: Estação Liberdade, 2005. p. 255-280.
} 
imposto. $^{17}$

Desse modo, não obstante os ideais revolucionários de liberdade e igualdade, podemos observar que a revolução americana foi, também, uma história de exclusão de gênero e de raça, e que ainda foram necessárias muitas lutas, após a revolução, rumo à universalização do sufrágio.

Na Europa ocidental, a Revolução Francesa, em 1789, rompeu com o regime monárquico e inaugurou a República, sendo a Declaração dos Direitos do Homem e do Cidadão considerada o "atestado de óbito" do Antigo Regime. $^{18}$ Para Comparato, o ideal de igualdade foi o ponto central do movimento revolucionário francês, que se preocupou em abolir uma série de desigualdades entre os homens. O autor enumera: foram extintas todas as servidões feudais, foi proclamada a emancipação dos judeus e a abolição de todos os privilégios religiosos em 1791, e proibiu-se o tráfico de escravos nas colônias em $1792 .{ }^{19}$

No entanto, não é segredo que a desigualdade entre os sexos não foi pauta desse movimento igualitário, permanecendo as mulheres, durante séculos, em situação de inferioridade em relação aos homens.

Olympe de Gouges redigiu uma Declaração dos Direitos da Mulher e da Cidadã, em 1791, em que criticava a o suposto "universalismo" da Declaração de 1789 e denunciava a exclusão da mulher. Entretanto, sua defesa dos direitos da mulher foi considerada "radical" e Olympe de Gouges foi presa por questionar os "valores republicanos" 20 , sendo condenada à morte e guilhotinada em 1793.

\footnotetext{
${ }^{17}$ SILVA, José Afonso da. Curso de Direito Constitucional Positivo. $37^{\mathrm{a}}$ ed rev. e atual. São Paulo: Malheiros, 2013. p. 158.

${ }^{18}$ COMPARATO, Fábio Konder. A afirmação histórica dos Direitos Humanos. p. 146.

${ }^{19}$ COMPARATO, Fábio Konder. A afirmação histórica dos Direitos Humanos. p. 133.

${ }^{20}$ VILLAMÉA, Luiza. Olympe de Gouges, a pioneira do feminismo que foi parar na guilhotina. Disponível em <https://www.geledes.org.br/pioneira-do-feminismo-que-foi-parar-na-guilhotina/>. Acesso em 3 de novembro de 2017.
} 
Assim, podemos observar mais uma vez como a exclusão esteve presente na sociedade após as revoluções liberais, apesar de fundadas nas ideias de igualdade e liberdade, e podemos compreender as críticas de Pateman à situação de sujeição da mulher no Estado liberal.

Por fim, não se pode deixar de mencionar outro projeto de constituição, frequentemente silenciado, forjado no mesmo contexto revolucionário: a Constituição do Haiti. A Revolução Haitiana, influenciada pela Revolução Francesa, nos mostra que o ideal de igualdade, considerado ponto central do movimento francês, além da exclusão de gênero, também não incorporava efetivamente a questão racial e de classe. A revolução iniciada no final do século XVIII culminou na independência da colônia francesa de São Domingos, sendo o novo estado batizado de Haiti. ${ }^{21}$ Em 1805, foi declarada a independência, firmando-se o primeiro Estado independente construído por exescravos e negros libertos. $^{22}$

O constitucionalismo haitiano trouxe uma nova concepção de liberdade na era revolucionária. De acordo com o professor Marcos Vinícius Lustosa Queiroz, liberdade, nas constituições haitianas, "invocava uma nova e radical articulação do conceito de raça e da relação entre liberdade e igualdade". ${ }^{23}$ Isso porque, no Haiti, diferentemente do que ocorria nos debates constitucionais europeus, a escravidão não era uma questão abstrata, filosófica. Era uma realidade, algo concreto, tendo o Haiti sido fundado justamente para assegurar a liberdade e abolir a submissão racial.

A constituição do Haiti pós-independência teve um dos projetos mais radicais e igualitários do século XIX. Um traço característico, por exemplo, foi

\footnotetext{
${ }^{21}$ QUEIROZ, Marcos Vinícius Lustosa. Constitucionalismo Brasileiro e o Atlântico Negro: a experiência constitucional de 1823 diante da Revolução Haitiana. Brasília. 2017. Dissertação (Mestrado em Direito, Estado e Constituição) - Programa de Pós-Graduação em Direito da Universidade de Brasília. p. 67.

${ }^{22}$ QUEIROZ, Marcos Vinícius Lustosa. Constitucionalismo Brasileiro e o Atlântico Negro. p. 67.

${ }^{23}$ QUEIROZ, Marcos Vinícius Lustosa. Constitucionalismo Brasileiro e o Atlântico Negro. p. 76.
} 
não disciplinar concretamente as formas de aquisição de cidadania haitiana; o Haiti oferecia cidadania para todos os indígenas, africanos e descendentes que passassem a residir em seu território. ${ }^{24}$

Essa breve referência ao constitucionalismo haitiano é importante para demonstrar que o significado de liberdade e igualdade na modernidade não é apenas aquele forjado a partir das revoluções francesa e americana. A revolução haitiana trouxe uma maneira diferente de se conceber a liberdade, com base em uma ideia de dominação mais radical em relação àquela concebida pelos revolucionários nos Estados Unidos e na França. ${ }^{25}$

Feitas essas considerações acerca das revoluções liberais, que, paradoxalmente, trouxeram a liberdade e a dominação, com alguns comentários sobre a história de exclusão originada no contrato social, se passará agora a apresentar algumas definições de conceitos chave para este trabalho. Busca-se, com isso, estabelecer a relação entre sufrágio e democracia, em que o primeiro é expressão necessária da segunda.

\subsection{DEMOCRACIA, CIDADANIA, SUFRÁGIO E VOTO}

José Afonso da Silva define democracia como um processo. Mais do que um regime político, para o autor, democracia é um "processo de convivência social em que o poder emana do povo, há de ser exercido, direta ou indiretamente, pelo povo e em proveito do povo" ${ }^{26}$. Assim, para além de ser uma relação de poder político, a democracia, segundo o jurista, é um modo de vida, um processo de afirmação do povo e de garantia de direitos

\footnotetext{
${ }^{24}$ QUEIROZ, Marcos Vinícius Lustosa. Constitucionalismo Brasileiro e o Atlâtico Negro. p. 75.

${ }^{25}$ Para uma análise detalhada do constitucionalismo haitiano, v. QUEIROZ, Marcos Vinícius Lustosa. Constitucionalismo Brasileiro e o Atlântico Negro.

${ }^{26}$ SILVA, José Afonso da. Curso de Direito Constitucional Positivo. p. 128.
} 
fundamentais.

A concepção de Abraham Lincoln de que a democracia é "governo do povo, pelo povo e para o povo" ${ }^{27}$ traz alguns pontos fundamentais do regime democrático, analisados por José Afonso da Silva. Em primeiro lugar, governo "do povo" revela que a titularidade do regime é do povo, segundo a conhecida máxima "todo poder emana do povo". Isso está em linha com o princípio da soberania popular firmado nos Estados liberais. Governo "pelo povo", por sua vez, significa que o governo democrático se baseia na vontade/consentimento popular, isto é, na adesão livre e voluntária do povo à autoridade. Na democracia representativa, essa adesão é efetivada através da técnica da representação. Por fim, governo "para o povo" é aquele que libere o homem de autoritarismos e garanta o máximo possível de segurança e bem-estar. ${ }^{28}$

Já Pinto Ferreira ${ }^{29}$ entende que a democracia, em sua acepção ampla e dialética, é "o governo constitucional das maiorias que, sobre as bases de uma relativa liberdade e igualdade, pelo menos a igualdade civil (a igualdade diante da lei), proporciona ao povo o poder de representação e fiscalização dos negócios públicos". ${ }^{30}$ Como governo das maiorias, realiza-se através do voto. Por isso, escreveu o constitucionalista, ao longo dos séculos observou-se a tendência das democracias à técnica da universalização do sufrágio. ${ }^{31}$

Existem, a rigor, três tipos de democracia: direta, indireta ou semidireta. $\mathrm{Na}$ democracia direta, como o nome indica, o povo exerce diretamente os poderes governamentais ${ }^{32}$. A democracia indireta (ou representativa) é aquela

\footnotetext{
${ }^{27}$ SILVA, José Afonso da. Curso de Direito Constitucional Positivo. p. 137.

${ }^{28}$ SILVA, José Afonso da. Curso de Direito Constitucional Positivo. p. 137.

${ }^{29}$ FERREIRA, Pinto. Curso de direito constitucional. 12 ed. ampl. e atual. São Paulo: Saraiva, 2002.

${ }^{30}$ FERREIRA, Pinto. Curso de direito constitucional. p. 79.

${ }^{31}$ FERREIRA, Pinto. Curso de direito constitucional. p. 79.

${ }^{32}$ Como ensina o historiador americano Moses Finley, o maior exemplo de democracia direta foi a ateniense, em que os cidadãos se reuniam em Assembleia para decidir diretamente sobre toda gama de questões governamentais. Segundo Finley, a Assembleia "detinha a palavra final na guerra e na paz, nos tratados, nas finanças, na legislação, nas obras públicas, em suma, na totalidade das atividades governamentais", e se organizava em forma de comício ao ar livre com todos os cidadãos que
} 
em que as funções de governo são outorgadas a representantes do povo (sendo o povo a fonte primária do poder), pois questões como extensão territorial, densidade demográfica e a complexidade das relações sociais impedem que o povo dirija os negócios do Estado diretamente. Já a democracia semidireta é uma democracia representativa com alguns institutos de participação direta, os quais integram a chamada democracia participativa. ${ }^{33}$

A título de exemplo, temos que a Constituição brasileira de 1988 consagra a democracia semidireta, combinando representação e participação direta, na forma de seu artigo $1^{\circ}$, parágrafo único: "todo o poder emana do povo, que o exerce por meio de representantes eleitos ou diretamente, nos termos desta Constituição".

Nas palavras de José Afonso da Silva, "é no regime de democracia representativa que se desenvolvem a cidadania $\mathrm{e}$ as questões de representatividade". ${ }^{34}$ Isso porque a democracia representativa pressupõe a existência de institutos que assegurem e disciplinem a participação popular na vida política, de modo a preservar a soberania popular. Esses institutos formam os chamados direitos políticos.

Nesse sentido, os direitos políticos são definidos por José Afonso da Silva como "a disciplina dos meios necessários ao exercício da soberania popular"35, enquanto Rosah Russomano entendia que "direitos políticos, em sua acepção restrita, encarnam o poder de que dispõe o indivíduo para

quisessem comparecer. É claro que, naquele momento, "povo" eram apenas os homens livres, ficando excluídos, ainda, os libertos. Escravos e libertos, que constituíam a maior parte da população, não eram considerados cidadãos e, portanto, não faziam parte do grupo que deliberava nas Assembleias e que exercia o poder político. FINLEY, M.I. Democracia antiga e moderna. Rio de Janeiro: Graal, 1988. $192 \mathrm{p}$.

${ }^{33}$ SILVA, José Afonso da. Curso de Direito Constitucional Positivo. p. 138.

${ }^{34}$ SILVA, José Afonso da. Curso de Direito Constitucional Positivo. p. 139.

${ }^{35}$ SILVA, José Afonso da. Curso de Direito Constitucional Positivo. p. 139. 
interferir na estrutura governamental, através do voto"36.

Pimenta Bueno, analisando os direitos políticos à luz da Constituição do Império, os conceituou como "as prerrogativas, os atributos, faculdades ou poder de intervenção dos cidadãos ativos no governo de seu país, intervenção direta ou só indireta, mais ou menos ampla, segundo a intensidade do gozo desses direitos",37.

Por sua vez, Pinto Ferreira descreve os direitos políticos como aqueles que "asseguram a participação do indivíduo no governo de seu país, seja votando ou sendo votado". ${ }^{38}$ Segundo o doutrinador, a concepção de direitos políticos foi desenvolvida principalmente por Sieyès, que definiu tais direitos como aqueles que permitem que os habitantes de um país tomem parte ativa na formação dos poderes públicos. ${ }^{39}$

A partir das conceituações descritas acima, fica claro que os direitos políticos se relacionam intimamente com a ideia de cidadania. Pimenta Bueno, como visto, usava o termo "cidadão ativo" para designar aqueles que intervinham no governo de seu país. De maneira geral, os autores entendem os direitos políticos como aqueles que asseguram que os indivíduos participem das atividades governamentais, sendo, portanto, equivalentes à noção de cidadania.

Para Manoel Gonçalves Ferreira Filho ${ }^{40}$, a cidadania é um status ligado ao regime político; é o status de nacional acrescido dos direitos políticos, entendidos como o direito de participar do processo governamental, especialmente através do voto.

\footnotetext{
${ }^{36}$ RUSSOMANO, Rosah. Curso de Direito Constitucional. $2^{\mathrm{a}}$ ed. São Paulo: Saraiva, 1972. Apud SILVA, José Afonso da. Curso de Direito Constitucional Positivo. p. 349.

${ }^{37}$ PIMENTA BUENO, José Antônio. Direito Público Brasileiro e Análise da Constituição do Império. Rio de Janeiro: Ministério da Justiça/Serviço de Documentação, 1958. Apud SILVA, José Afonso da. Curso de Direito Constitucional Positivo. p. 349.

${ }^{38}$ FERREIRA, Pinto. Curso de direito constitucional. p. 166.

${ }^{39}$ FERREIRA, Pinto. Curso de direito constitucional. p. 1173.

${ }^{40}$ FERREIRA FILHO, Manoel Gonçalves. Curso de Direito Constitucional. p. 99.
} 
José Afonso da Silva afirma que cidadania "qualifica os participantes da vida do Estado, é atributo das pessoas integradas na sociedade estatal, atributo político decorrente do direito de participar no governo e direito de ser ouvido pela representação política". ${ }^{41}$

Esses conceitos nos permitem observar que as mulheres, excluídas por séculos da categoria dos eleitores, não eram participantes da vida do Estado (esfera pública), ficando sua existência restrita somente à vida doméstica (esfera privada). Sem terem seus direitos políticos assegurados, as mulheres não possuíam o direito de ser ouvidas pela representação política. Conforme se verá nos capítulos dois e três deste trabalho, a luta das mulheres pelo sufrágio seja na Inglaterra, Estados Unidos, no Brasil e em outros países da América Latina - representava o reconhecimento das mulheres de que o voto não era um fim em si mesmo, mas sim uma maneira de intervir no processo político e de ser ouvidas pelos representantes, para assim assegurar e conquistar outros direitos.

O núcleo dos direitos políticos é o direito de votar e ser votado, o que permite que a doutrina vislumbre a existência direitos políticos ativos (direito de votar) e passivos (direito de ser votado). Não são divisões, mas sim modalidades dos direitos políticos, que dizem respeito ao seu exercício.

O sufrágio é um dos principais institutos dos direitos políticos, o qual abrange tanto o direito de votar quanto o direito de ser votado. Comumente, as expressões "sufrágio" e "voto" são empregados indistintamente, como sinônimos. Entretanto, a doutrina estabelece a diferença entre os termos: o sufrágio é o direito, enquanto o voto é o seu exercício.

O sufrágio, segundo Carlos S. Fayt, citado por José Afonso da Silva, é um direito público subjetivo de natureza política, que confere ao cidadão o

\footnotetext{
${ }^{41}$ SILVA, José Afonso da. Curso de Direito Constitucional Positivo. p. 350.
} 
poder de eleger, ser eleito e de participar da organização da atividade do poder estatal. ${ }^{42} \mathrm{O}$ sufrágio é a instituição fundamental da democracia representativa, pois é mediante o seu exercício que o povo outorga legitimidade aos representantes. Nas democracias semidiretas (que, como visto, possuem instrumentos de participação direta), o sufrágio também é exercido por meio do plebiscito e referendo. O direito ao sufrágio decorre diretamente do princípio de que todo poder emana do povo e essencialmente é o que legitima o exercício do poder em uma democracia. ${ }^{43}$

A doutrina diferencia as formas de sufrágio entre sufrágio universal e restrito (censitário, capacitário, etc.). Atualmente, se considera que se o regime é democrático, o sufrágio necessariamente é universal. Sufrágio universal é aquele conferido a todos os indivíduos de um país, sem restrições discriminatórias, como condições de cunho econômico, sexual, racial ou profissional. Além disso, a democracia também exige o sufrágio igual, isto é, que cada eleitor possua o mesmo número de votos que os demais e que cada voto tenha o mesmo peso. É a máxima "one man, one vote" (um homem, um voto).

O voto, por sua vez, é a manifestação prática do sufrágio, é o seu exercício. Discute-se a natureza do voto: se é um direito, uma função ou um dever. Para José Afonso da Silva, o voto é um direito, uma função social (função da soberania popular, visto que traduz o seu instrumento de atuação) e, ao mesmo tempo, um dever. É um dever social, político, pois a democracia representativa exige que sejam eleitos representantes pelo voto dos cidadãos, de modo que o indivíduo tem o dever de votar, sob pena de inviabilizar o próprio instituto da representação. A qualificação do voto como dever social independe da obrigatoriedade jurídica do voto; existe seja o voto facultativo ou

\footnotetext{
${ }^{42}$ SILVA, José Afonso da. Curso de Direito Constitucional Positivo. p. 353.

${ }^{43}$ SILVA, José Afonso da. Curso de Direito Constitucional Positivo. p. 353.
} 
obrigatório. $^{44}$

Em suma, enquanto o sufrágio é o direito em si, o voto é o seu instrumento, sua materialização, que ocorre mediante o exercício do direito. Não obstante a referida distinção teórica, cabe esclarecer que, neste trabalho, os termos "sufrágio" e "voto" poderão ser utilizados como sinônimos, devendo ser compreendidos como o direito em si.

Com base nos conceitos expostos neste capítulo, pode ser compreendido como o sufrágio universal é necessário para a plenitude da democracia. Voltando ao conceito de Lincoln de que a democracia é "governo do povo, pelo povo e para o povo", vê-se que o exercício do poder em regimes democráticos só é legitimado pelo voto, na medida em que é por meio desse instrumento que os cidadãos elegem aqueles que irão representá-los na atividade governamental.

Entretanto, mesmo com os ideais de igualdade propagados pelas revoluções liberais do século XVIII, as mulheres ficaram excluídas da vida política por mais de um século após tais revoluções. A elas eram vedados os direitos políticos, ficando o sufrágio restrito aos homens. Foi preciso mais de um século de lutas e mobilizações para que as mulheres conquistassem espaço na vida pública. A luta pelo sufrágio sintetiza a reivindicação por igualdade política como forma de superar desigualdades e conquistar outros direitos, como se verá neste trabalho.

Após essas considerações acerca de alguns conceitos determinantes para a melhor compreensão do significado da luta pelo direito ao voto, os próximos capítulos versarão sobre a conquista do sufrágio feminino, em uma luta iniciada principalmente no século XIX e que se estendeu também pelas primeiras décadas do século XX. Serão abordados os movimentos sufragistas

\footnotetext{
${ }^{44}$ SILVA, José Afonso da. Curso de Direito Constitucional Positivo. p. 362.
} 
da Inglaterra, dos Estados Unidos e de alguns países da América Latina, para depois ser examinado mais detalhadamente o movimento brasileiro. 


\section{CONTEXTO MUNDIAL: A EXPERIÊNCIA SUFRAGISTA NA INGLATERRA, ESTADOS UNIDOS E AMÉRICA LATINA}

\subsection{INGLATERRA}

Considerado um marco do feminismo moderno, o livro $A$ Vindication of the Rights of Woman, escrito pela inglesa Mary Wollstonecraft foi publicado em 1792. A autora abordava a desigualdade social e política entre homem e mulher, que, argumentava, decorreria da educação restrita e do cerceamento da liberdade da mulher. O livro alcançou grande popularidade na Inglaterra e nos EUA, tornando-se fonte de inspiração para as futuras gerações de feministas. ${ }^{45}$

Já no século XVIII, portanto, Mary Wollstonecraft defendeu que posição de submissão social, civil e política em que se encontravam as mulheres da época somente seria superada se a educação fosse universal e igual e se as mulheres possuíssem representantes no governo. Por esse motivo, $A$ Vindication of the Rights of Woman é considerado o primeiro manifesto feminista da história da Inglaterra. ${ }^{46}$

O movimento sufragista inglês, em sua origem, surgiu ligado a outros movimentos libertários, como o abolicionismo e o cartismo (movimento operário inglês que lutava contra a exploração de trabalhadores). Nas décadas de 1830 e 1840, as mulheres inglesas começaram a participar de tais movimentos. Em 1847, Anne Knight (1786-1862), militante cartista e abolicionista, fundou a primeira Female Political Association britânica, em Sheffield, tendo como principal objetivo a luta pelo sufrágio feminino. Em uma das assembleias de tal associação, foi elaborada uma petição pelo sufrágio, que foi submetida à Câmara dos Lordes em 1851 pelo Conde de

\footnotetext{
${ }^{45}$ ABREU, Zina. Luta das mulheres pelo direito de voto: movimentos sufragistas na Grã-Bretanha e nos Estados Unidos. ARQUIPÉLAGO-Revista da Universidade dos Açores, 2002. pp. 443 e 444.

${ }^{46}$ ABREU, Zina Abreu. Luta das mulheres pelo direito de voto. pp. 449 e 450.
} 
Carlisle. $^{47}$

O filósofo inglês John Stuart Mill (1806-1873) foi um importante defensor do sufrágio feminino no país. Stuart Mill tecia fortes críticas à posição de subordinação da mulher na sociedade. Escreveu ele: "To have a voice in choosing those by whom one is to be governed is a means of selfprotection due to every one ${ }^{\text {"48 }} .^{49}$ Stuart Mill foi, por sua vez, influenciado pelas ideias feministas de sua mulher, Harriet Taylor Mill (1807-1858), que defendeu o direito ao voto feminino em seu ensaio Enfranchisement of Women, datado de $1851 .{ }^{50}$

Stuart Mill, eleito deputado em 1856, submeteu à Câmara dos Comuns nova petição pelo sufrágio feminino, elaborada por um comitê de mulheres (Women's Suffrage Committee), fundado em 1866 por Jesse Boucherett, Rosamund Hill e Elizabeth Garret. Até 1884, foram apresentadas à Câmara dos Comuns mais duas petições exigindo direito ao voto feminino, com mais de 3 mil assinaturas. ${ }^{51}$ Dentre as signatárias das petições, encontravam-se a poetisa Florence Nightingale, a reformadora política Harriet Martineau e a matemática Mary Somerville. Apesar de, já nessa época, oitenta deputados terem votado favoravelmente ao sufrágio feminino, não foi um número suficiente para aprovação da petição. ${ }^{52}$

O século XIX na Inglaterra foi marcado por uma série de reformas na lei eleitoral. Em 1832, houve a Primeira Reforma Eleitoral, que redistribuiu o número de assentos na Câmara dos Comuns e aumentou o número de eleitores do país. Com essa lei, aos homens que já possuíam direito de voto - os proprietários de terras - se juntaram meio milhão de eleitores do sexo

\footnotetext{
${ }^{47}$ ABREU, Zina Abreu. Luta das mulheres pelo direito de voto. p. 458.

${ }^{48}$ Em tradução livre, "ter voz na escolha daqueles por quem seremos governados é um meio de autoproteção a que todos têm direito".

${ }^{49}$ ABREU, Zina Abreu. Luta das mulheres pelo direito de voto. p. 456.

${ }^{50}$ ABREU, Zina Abreu. Luta das mulheres pelo direito de voto. p. 456.

${ }^{51}$ ABREU, Zina Abreu. Luta das mulheres pelo direito de voto. p. 459.

${ }^{52}$ ABREU, Zina Abreu. Luta das mulheres pelo direito de voto. p. 459.
} 
masculino. ${ }^{53}$ Contudo, essa lei introduziu, pela primeira vez, o termo "masculino" na designação dos eleitores, formalizando expressamente a exclusão das mulheres da condição de eleitoras (assim como a $14^{\mathrm{a}}$ emenda à Constituição norte-americana veio a fazer em 1866).

A Segunda Reforma Eleitoral ocorreu em 1867, novamente ampliando o número de eleitores em aproximadamente dois milhões e meio de homens. ${ }^{54}$ Em 1884, a Terceira Reforma à lei eleitoral conferiu, pela primeira vez, direito de voto aos trabalhadores assalariados, aumentando em mais cinco milhões o número de eleitores. Com isso, aproximadamente dois terços da população masculina adulta possuía direitos políticos, ficando excluídos apenas os homens "mais pobres, os servos, os criminosos e os lunáticos".55

As sufragistas perceberam que os homens protegiam seus direitos e interesses por meio da legislação parlamentar, concluindo, portanto, que a condição social, econômica e educacional das mulheres só melhoraria quando os parlamentares tivessem de responder a um eleitorado feminino. Dessa forma, o sufrágio era um meio para atingir um fim, era um instrumento para que as desigualdades entre os sexos pudessem ser corrigidas. ${ }^{56}$

De acordo com Maria Zina Abreu, foram estabelecidas diferentes denominações para se referir às mulheres que lutavam pelo sufrágio feminino na Inglaterra, conforme o tipo de militância. As "sufragistas" eram aquelas que utilizavam métodos moderados e pacíficos, também conhecidas como "sufragistas constitucionalistas". A organização sufragista britânica mais influente era a National Union of Women's Suffrage Societies (NUWSS), fundada em 1897 e liderada por Millicent Garret Fawcett. As "sufragetes", por sua vez, possuíam estratégia mais agressiva, diferentemente da moderação da

\footnotetext{
${ }^{53}$ ABREU, Zina Abreu. Luta das mulheres pelo direito de voto. p. 459.

${ }^{54}$ ABREU, Zina Abreu. Luta das mulheres pelo direito de voto. p. 460.

${ }^{55}$ ABREU, Zina Abreu. Luta das mulheres pelo direito de voto. p. 460.

${ }^{56}$ ABREU, Zina Abreu. Luta das mulheres pelo direito de voto. p. 460.
} 
NUWSS, que tinha se revelado bastante ineficaz. As sufragetes faziam parte da Women's Social and Political Union (WSPU), fundada em 1903 pelas Pankhursts (Emmeline, a presidente, e suas filhas Christabel, Sylvia e Adela).

A WSPU tinha como lema a frase "Deeds not words" (ações e não palavras) e adotava uma militância mais combativa, com o objetivo de incomodar o governo até conseguir o direito ao voto ${ }^{57}$ :

as sufragetes molestavam os políticos, interrompiam-nos e interrogavam-nos; desafiavam os deputados liberais; marcavam nos passeios os avisos de comícios e ações a serem levadas a cabo; partiam em bicicletas para divulgar as ações da WSPU pelos subúrbios londrinos, reuniam-se com as operárias às portas das fábricas na hora do almoço, produziam e encarregavam-se da distribuição da propaganda da WSPU por todo o Reino Unido. ${ }^{58}$

Todavia, essas ações não surtiram fortes efeitos perante o Governo e o Parlamento, o que fez com que, principalmente a partir de 1908, as sufragetes passassem a adotar métodos cada vez mais violentos e agressivos, como vandalizar ou destruir prédios, igrejas e museus, provocar incêndios, quebrar vidraças, etc. ${ }^{59}$ Esse movimento mais radical provocou forte reação por parte das autoridades, resultando no encarceramento de centenas de sufragetes. Muitas mulheres fizeram greve de fome como forma de protesto, ao que o Governo, buscando evitar mortes que resultassem na produção de mártires, respondeu com a prática da alimentação forçada, por meio de um tubo introduzido forçadamente pela boca, processo cruel considerado tortura. ${ }^{60}$

Conforme salienta Maria Zina Abreu, foi apenas aí que a luta pelo sufrágio feminino passou a ser levada a sério pelos políticos e pela imprensa britânica. Em 1918, foi aprovada pelo Parlamento uma nova lei de reforma eleitoral que conferia o direito de voto às mulheres britânicas - a chamada

\footnotetext{
${ }^{57}$ ABREU, Zina Abreu. Luta das mulheres pelo direito de voto. p. 462.

${ }^{58}$ ABREU, Zina Abreu. Luta das mulheres pelo direito de voto. p. 463.

${ }^{59}$ ABREU, Zina Abreu. Luta das mulheres pelo direito de voto. p. 464.

${ }^{60}$ ABREU, Zina Abreu. Luta das mulheres pelo direito de voto. p. 464.
} 
Representation of the People Act. ${ }^{61}$

Contudo, a referida lei ainda estabelecia discriminação entre os sexos com relação à idade (o homem podia ser eleitor aos 21 anos, enquanto a mulher apenas aos 30). A igualdade de direitos políticos só veio a ser alcançada, na Inglaterra, com a promulgação do Equal Enfranchise Act, em $1928 .{ }^{62}$

O movimento sufragista inglês, que nasceu de mãos dadas com articulações de outros grupos marginalizados, como os escravos e os operários, influenciou em grande medida os sufragismos norte-americano e brasileiro. A situação conturbada da Inglaterra teve forte repercussão no Brasil, instalandose certo medo de que os métodos das sufragetes fossem repetidos neste país, o que fez com que a imprensa se colocasse fortemente contrária ao movimento sufragista brasileiro durante algumas décadas. Nos Estados Unidos, como veremos a seguir, a fase mais radical do movimento foi inspirada diretamente pelas táticas que as Pankhurst já aplicavam na Inglaterra.

\subsection{ESTADOS UNIDOS}

Assim como na Inglaterra, a luta pelo sufrágio feminino nos Estados Unidos surgiu intimamente ligada ao movimento abolicionista. No contexto colonial, segundo a historiadora Branca Moreira Alves, a família era considerada uma unidade de produção, sem uma delimitação clara das tarefas domiciliares entre trabalho masculino, feminino e infantil. $\mathrm{O}$ regime característico das treze colônias era de pequena propriedade, em que

\footnotetext{
${ }^{61}$ ABREU, Zina Abreu. Luta das mulheres pelo direito de voto. pp. 464 e 465.

${ }^{62}$ BESTER, Gisela Maria. Direitos políticos das mulheres brasileiras: aspectos históricos da luta sufrágica e algumas conquistas políticas posteriores. Florianópolis. 1996. Dissertação (Mestrado em Ciências Humanas - Especialidade Direito) - Centro de Ciências Jurídicas da Universidade Federal de Santa Catarina. p. 104.
} 
praticamente todos os membros da família produziam e não havia uma valoração maior ao trabalho do homem (tipicamente trabalho no campo) em detrimento do da mulher (mais voltado para a indústria doméstica), ainda que a mulher fosse submetida, do ponto de vista legal e cultural, ao homem. ${ }^{63}$ Isso veio a mudar com o crescimento da urbanização, que ocasionou uma maior distinção entre trabalho doméstico (mundo feminino) e extradoméstico (mundo masculino). A subsistência familiar passou a depender do salário do homem, reduzindo o peso e importância dada ao trabalho da mulher na produção da família. ${ }^{64}$

As colônias do Norte, no início do século XIX, deram início à luta contra a escravidão. $\mathrm{O}$ movimento abolicionista acabou funcionando como ponte para as mulheres expressarem seus interesses. Conforme explica Moreira Alves, a sociedade da época tinha maior facilidade em identificar as mulheres com uma causa humanitária como a abolição da escravidão, que seria compatível com os "sentimentos femininos", e, por isso, era considerado perdoável que a mulher quebrasse os costumes para falar em público. ${ }^{65}$

Inicialmente, esse público era apenas feminino, mas logo passou a ser composto tanto por homens quanto por mulheres. Quando determinadas mulheres passaram a falar para plateias mistas, que incluíam homens desconhecidos, houve uma forte reprovação face a tamanha ousadia. Foi nesse momento que as mulheres abolicionistas perceberam e se convenceram da sua própria submissão. Ao participarem desse processo de organização política e se depararem com grande resistência, entenderam que só poderiam ter voz nas decisões políticas quando representassem uma força eleitoral. ${ }^{66}$

\footnotetext{
${ }^{63}$ ALVES, Branca Moreira. Ideologia e feminismo: a luta da mulher pelo voto no Brasil. Petrópolis: Vozes, 1980. p. 65.

${ }^{64}$ ALVES, Branca Moreira. Ideologia e feminismo. p. 66.

65 ALVES, Branca Moreira. Ideologia e feminismo. p. 67.

${ }^{66}$ ALVES, Branca Moreira. Ideologia e feminismo. p. 67.
} 
Em 1830, foram criadas diversas associações femininas abolicionistas, que serviriam posteriormente como base para as mobilizações pelos direitos da mulher. Por certo, já houve resistência masculina: a Igreja Congregacional de Massachusetts protestou contra as primeiras mulheres que se manifestaram perante um público misto, as irmãs Angelina e Sarah Grimké, que também sofreram críticas dos líderes abolicionistas, os quais consideravam a opressão da mulher um mal menor do que a situação dos escravos. ${ }^{67}$

Em 1848, Lucretia Mott, líder abolicionista, e Elizabeth Cady Stanton, que viria a se tornar uma importante líder feminista, organizaram uma reunião pública, a Convenção dos Direitos de Mulher, em Seneca Falls. Lá apresentaram uma Declaração de Princípios, inspirada na Declaração de Independência norte-americana, denunciando a opressão exercida pelos homens sobre as mulheres: estas eram obrigadas a obedecer a leis criadas sem a sua participação, eram consideradas "civilmente mortas" perante a lei após o casamento, recebiam ínfima remuneração pelo seu trabalho (quando lhes era permitido trabalhar), tiveram sua autoconfiança e respeito próprio rebaixados de modo a terem uma vida de dependência e submissão. ${ }^{68}$

Concluía a Declaração: "Fica resolvido: que é dever das mulheres deste país assegurar para si o direito sagrado do sufrágio"69. Enquanto todas as outras resoluções da Declaração foram aprovadas unanimemente, a reivindicação pelo voto feminino dividiu a audiência. Henry Stanton, líder abolicionista e marido de Elizabeth, que havia redigido o documento, se retirou do local em protesto. Ainda assim, a resolução defendendo o sufrágio feminino acabou sendo aprovada na Convenção.

\footnotetext{
${ }^{67}$ ALVES, Branca Moreira. Ideologia e feminismo. p. 67.

${ }^{68}$ ALVES, Branca Moreira. Ideologia e feminismo. pp. 67 e 68.

${ }^{69}$ KOEDT, Anne; LEVINE, Ellen; RAPONE, Anita. Radical Feminism. Nova Iorque: Quadrangle Books, 1973, pp. 7 e 8. Apud ALVES, Branca Moreira. Ideologia e feminismo. p. 69.
} 
A partir dessa reunião de Seneca Falls, o pleito pela emancipação feminina deixou de ser uma ambição de poucas e passou a ganhar força entre milhares de mulheres. Surgiram novas lideranças, tais como Lucy Stone, Susan B. Anthony e Antoinette Brown, e foram realizadas inúmeras convenções feministas.

Em 1851, foi realizada uma convenção pelos direitos da mulher, a Women's Rights Convention, em Akron, Ohio. Na reunião, Sojourner Truth fez uma intervenção emblemática, posteriormente intitulada "Ain't I a Woman?",70, diante das manifestações de pastores que afirmavam que mulheres não deveriam ter os mesmos direitos que os homens:

Aqueles homens ali dizem que as mulheres precisam de ajuda para subir em carruagens, e devem ser carregadas para atravessar valas, e que merecem o melhor lugar onde quer que estejam. Ninguém jamais me ajudou a subir em carruagens, ou a saltar sobre poças de lama, e nunca me ofereceram melhor lugar algum! E não sou uma mulher? Olhem para mim? Olhem para meus braços! Eu arei e plantei, e juntei a colheita nos celeiros, e homem algum poderia estar à minha frente. E não sou uma mulher? Eu poderia trabalhar tanto e comer tanto quanto qualquer homem - desde que eu tivesse oportunidade para isso - e suportar o açoite também! E não sou uma mulher? Eu pari treze filhos e vi a maioria deles ser vendida para a escravidão, e quando eu clamei com a minha dor de mãe, ninguém a não ser Jesus me ouviu! E não sou uma mulher? ${ }^{71}$

Sojourner Truth havia sido escrava, tornando-se livre em 1787, e foi uma líder abolicionista e defensora dos direitos das mulheres. Seu discurso retrata a posição da mulher negra no contexto do feminismo, unindo raça e condição social à questão sexual, e é até hoje considerado um importante marco na luta pela igualdade racial e de gênero.

Até 1867 , o movimento feminista e o movimento abolicionista andaram juntos. Contudo, a reunião da American Equal Rights Association, cujo objetivo era defender os direitos tanto dos negros quanto das mulheres, marcou

\footnotetext{
${ }^{70}$ Em tradução livre, "E não sou uma mulher?".

${ }^{71}$ TRUTH, Sojourner. E não sou uma mulher?. Tradução de Osmundo Pinho. Disponível em < https://www.geledes.org.br/e-nao-sou-uma-mulher-sojourner-truth/>. Acesso em 4 de novembro de 2017.
} 
a cisão dos dois movimentos. No referido encontro, ficou resolvido que a Emenda Constitucional $\mathrm{n}^{\circ} 14$ seria defendida; tal emenda incluía a palavra "masculino" para a qualificação da cidadania, conferindo direito a voto ao total de "cidadãos do sexo masculino" maiores de 21 anos em cada Estado. ${ }^{72}$ Isto é, decidiu-se apoiar uma emenda que confirmava a exclusão da mulher da condição de eleitora. Segundo Moreira Alves, Elizabeth Cady Stanton e Susan B. Anthony foram veementemente contrárias à emenda, afirmando que ela atrasaria a luta pelo sufrágio feminino em 100 anos.

Os abolicionistas passaram a rejeitar os vínculos com a causa feminista. Susan B. Anthony e Elizabeth Stanton, percebendo a imperatividade de que as mulheres lutassem por si mesmas, fundaram, em 1868, a National Woman Suffrage Association (NWSA) em Nova Iorque, voltada para defender, junto ao Congresso Nacional, a elaboração de uma emenda constitucional que autorizasse o sufrágio feminino. Criaram, também, o jornal The Revolution, em que teciam críticas às leis e costumes da época, bem como ao papel da Igreja na perpetuação da sujeição da mulher, e defendiam, além do sufrágio, temas como o divórcio e as causas da mulher operária. $\mathrm{O}$ voto era encarado não como um fim em si mesmo, mas como um instrumento para ajudar a combater a exclusão política da mulher. ${ }^{73}$

Em 1869, um grupo de mulheres e homens (diferentemente da NWSA, que só permitia a entrada de mulheres) cria a American Woman Suffrage Association (AWSA), liderada por Henry Beecher, Lucy Stone e Julia Ward Howe. A AWSA era mais conservadora quando comparada à NWSA, de linha mais radical, e restringia seu pleito à obtenção dos direitos políticos e civis da mulher. A estratégia visada pela AWSA era uma atuação a nível estadual, buscando conquistar o voto por meio de plebiscitos para alterar as

\footnotetext{
${ }^{72}$ ALVES, Branca Moreira. Ideologia e feminismo. p. 70.

${ }^{73}$ ALVES, Branca Moreira. Ideologia e feminismo. p. 72.
} 
constituições estaduais, enquanto a NWSA queria atuar diretamente no Congresso para uma emenda à Constituição Federal.

Por duas décadas, ambas as associações funcionaram em paralelo, ainda que houvesse um sentimento de desconfiança mútua. A tática utilizada era a mesma: movimentar a opinião pública por meio de conferências, abaixoassinados e publicações em jornais.

Elizabeth Stanton e Susan B. Anthony, assim como Emma Goldman, perceberam que a condição de sujeição da mulher estava intimamente relacionada com sua posição dentro da família. Para mudar isso, seria necessário atacar lentamente os valores do modelo de sociedade vitoriana, para assim poder mudá-los gradativamente, em vez de buscar uma ruptura radical com tais valores. Aos poucos, a NWSA se viu obrigada a esfriar sua argumentação e restringir as reivindicações à defesa dos direitos políticos femininos, não mais a uma crítica profunda da conjuntura cultural, econômica e institucional da sociedade norte-americana que levava à situação de inferioridade social da mulher.

Em 1890, a corrente radical (NWSA) se fundiu com os conservadores (AWSA), dando origem à National American Woman's Suffrage Association (NAWSA), de modo a conquistar maior apoio popular à causa pelo voto feminino. As ideias relativas a divórcio e amor livre, assim como as críticas mais profundas à estrutura familiar, educacional, religiosa da sociedade foram deixadas de lado, para evitar colocar o movimento pelo sufrágio a perder. ${ }^{74}$

Ainda no final do século XIX, outros movimentos femininos de classe média dialogavam com as sufragistas, tais como o Temperance Movement, que defendia a abstinência de bebida alcóolica e fez com que grupos envolvidos com a produção e comércio de álcool financiassem campanhas anti-sufragistas,

\footnotetext{
${ }^{74}$ ALVES, Branca Moreira. Ideologia e feminismo. pp. 74 e 75.
} 
e o Settlement Houses, que buscava auxiliar os imigrantes que viviam nos guetos das grandes cidades sem qualquer tipo de assistência governamental. ${ }^{75}$ Essas associações filantrópicas, assim como havia feito o movimento abolicionista, funcionaram como ponte para outras mulheres de classe média se envolverem com o sufragismo.

No final do século XIX e início do século XX, a NAWSA adquiriu caráter conservador, distanciando-se cada vez mais da classe trabalhadora. $\mathrm{O}$ discurso das sufragistas passou a ter cunho utilitarista, pragmático; buscava-se convencer o homem branco de classe média que o voto da mulher serviria para fortalecer o dele frente à ameaça do voto de imigrantes. Assim, pode-se afirmar que o movimento se tornou classista, preocupado com a emancipação da mulher burguesa. ${ }^{76}$

Entretanto, conforme análise de Adriana Vidal de Oliveira, é importante notar que o feminismo não nasceu liberal e limitado aos direitos individuais. As reivindicações das sufragistas, como Elizabeth Stanton e Susan B. Anthony, iam além do direito ao voto, encarado como um instrumento, um ponto de partida, abrangendo questões sociais, culturais e religiosas que contribuiriam para a perpetuação da sujeição feminina. Porém, naquele momento, elas optaram por recuar nas reivindicações para não prejudicar a luta pelo sufrágio. Assim, o feminismo liberal, embora tenha sido um marco na ampliação dos direitos das mulheres, não pretendia esgotar a luta feminina. ${ }^{77}$

Até a década de 1910, a NAWSA sofreu sucessivas derrotas na campanha de Estado por Estado (buscando realizar plebiscitos para alterar as constituições estaduais). A oposição era bastante poderosa: as principais forças anti-sufragistas eram a indústria de bebidas, os chamados corruptos de

\footnotetext{
${ }^{75}$ ALVES, Branca Moreira. Ideologia e feminismo. p. 75.

${ }^{76}$ ALVES, Branca Moreira. Ideologia e feminismo. pp. 76 e 77.

${ }^{77}$ OLIVEIRA, Adriana Vidal de. A Constituição da Mulher Brasileira: uma análise dos estereótipos de gênero na Assembleia Constituinte de 1987-1988 e suas consequências no texto constitucional. Rio de Janeiro. 2012. Tese (Doutorado em Direito) - Departamento de Direito da PUC-Rio. p. 117.
} 
manipulação política ("political machines") e o Movimento Anti-Sufragista (ainda que tivesse menor força que os dois primeiros grupos). ${ }^{78}$

A segunda geração das sufragistas (como Carrie Chapman Catt e Anne Howard Shaw), que no século XX compunham e lideravam a NAWSA, era mais conservadora que suas antecessoras. Até 1916, Anne H. Shaw ficou na presidência da associação, empregando as táticas de luta Estado por Estado, petições, conferências, reuniões, passeatas com cartazes iluminados, carros alegóricos, etc. Tiveram algumas vitórias: até 1913, a mulher podia votar em 9 Estados, tais como Washington e Califórnia. ${ }^{79}$ Porém, o número de derrotas também era alto e acabou convencendo a NAWSA a levar a luta ao Congresso, buscando uma emenda à Constituição Federal.

No século XX, foram criadas diversas outras organizações sufragistas nos EUA, algumas delas em razão do sentimento de decepção com o conservadorismo que a NAWSA havia adquirido. Harriet Stanton Blatch, filha de Elizabeth Stanton, fundou a Women's Political Union em 1907 e Alice Paul fundou a Congressional Union, que posteriormente se tornou o Woman's Party.

A Women's Political Union (WPU) veio com o objetivo de unir mulheres de várias classes sociais, com ênfase na mulher trabalhadora, tanto a operária quanto a profissional liberal. A organização introduziu a tática de realizar comícios diante de fábricas e levar operárias para depor nas comissões legislativas. ${ }^{80}$ Líderes sindicais como Charlotte Perkins Gilman e Florence Kelly se uniram à WPU, conferindo ao movimento a colaboração da mulher operária. Com isso, a tônica do discurso mudou e os pleitos passaram a incluir não somente igualdade de oportunidades educacionais e políticas (que beneficiariam essencialmente a mulher burguesa), mas também aumento

\footnotetext{
${ }^{78}$ ALVES, Branca Moreira. Ideologia e feminismo. p. 78.

${ }^{79}$ ALVES, Branca Moreira. Ideologia e feminismo. p. 80.

${ }^{80}$ ALVES, Branca Moreira. Ideologia e feminismo. p. 81.
} 
salarial, melhores condições de higiene e segurança nas fábricas, seguro de acidentes, férias remuneradas, etc. ${ }^{81}$ Ainda que essa corrente tenha sido minoritária, considerada por Branca Moreira Alves como uma exceção dentro do movimento sufragista norte-americano, foi importante na medida em que evidenciou a participação de mulheres de classes sociais mais baixas no movimento.

Por sua vez, a Congressional Union for Woman Suffrage (CUWS), fundada em 1913 por Alice Paul, teve grande repercussão perante a opinião pública por sua militância mais radical. Alice Paul participara do movimento sufragista inglês juntamente com as Pankhurst, que apresentavam métodos mais violentos (violência simbólica, isto é, sem danos às pessoas, apenas à propriedade). A Women's Social and Political Union, fundada pelas Pankhurst na Inglaterra em 1903, utilizava táticas de confrontação, o que levou a conflitos com a polícia, prisões e greves de fome, como visto anteriormente.

Alice Paul, após voltar aos EUA e se deparar com a NAWSA ainda realizando campanhas e petições, pensa que as estratégias tradicionais estariam ultrapassadas. Assim, em 1913 funda a CUWS e organiza uma passeata em Washington, desejando chamar a atenção pública para a causa. O que era para ser uma passeata como outras que alguns Estados norte-americanos já haviam vivenciado foi, contudo, a primeira lição de violência experimentada pela nova geração de sufragistas. ${ }^{82}$ As mulheres foram vaiadas, empurradas e agredidas diante da polícia, que nada fez. Antes disso, apenas as sufragistas pioneiras haviam vivenciado ataques semelhante - haviam sido ridicularizadas, agredidas verbal e fisicamente. Em palestras, pessoas atiravam tomates e ovos nas oradoras, e houve episódios em que elas foram, inclusive, apedrejadas. ${ }^{83}$

\footnotetext{
${ }^{81}$ ALVES, Branca Moreira. Ideologia e feminismo. p. 81.

${ }^{82}$ ALVES, Branca Moreira. Ideologia e feminismo. p. 82.

${ }^{83}$ ALVES, Branca Moreira. Ideologia e feminismo. pp. 79 e 82.
} 
A partir daí, foram organizadas diversas marchas em Washington, na frente da Casa Branca. No período de campanha de guerra, as mulheres passaram a empunhar cartazes questionando a democracia americana e fazendo referência à guerra, o que fez com que elas fossem agredidas pelos transeuntes e, logo, também pela polícia.

Iniciou-se no ano de 1917 uma fase semelhante ao que já era verificado na Inglaterra: prisões abusivas, maus tratos, greves de fome, alimentação forçada ${ }^{84}$ Menos de um ano depois, as autoridades se viram forçadas a liberar todas as sufragistas presas. Assim como na Inglaterra, a arbitrariedade das autoridades serviu para trazer a causa à atenção do público, gerando forte indignação popular, o que tornou inadiável a discussão sobre o sufrágio a nível político federal. No mesmo ano, o Congresso nomeou uma comissão para o sufrágio feminino.

Enquanto isso, a NAWSA, liderada por Carrie Chapman Catt, continuou com a luta em âmbito estadual e criticava publicamente os métodos “militantes" da Congressional Union. ${ }^{85}$

Em janeiro de 1918, a Câmara dos Deputados aprovou o projeto de emenda que tratava do sufrágio feminino. A emenda passou também pelo Senado, não sem a persistência e luta das sufragistas. ${ }^{86}$ Em setembro de 1920, foi ratificada a $19^{\mathrm{a}}$ emenda constitucional, que garantia o direito de voto a todas as mulheres americanas, com o seguinte texto: "The right of citizens of the United States to vote shall not be denied or abridged by the United States or by any State on account of sex". 87

\footnotetext{
${ }^{84}$ ALVES, Branca Moreira. Ideologia e feminismo. p. 83.

${ }^{85}$ ALVES, Branca Moreira. Ideologia e feminismo. p.84.

${ }^{86}$ ALVES, Branca Moreira. Ideologia e feminismo. pp. 84 e 85.

87 "O direito ao voto dos cidadãos dos Estados Unidos não será negado ou restringido pelos Estados Unidos ou por qualquer Estado por razões de sexo" (tradução livre). Disponível em $<$ https://www.archives.gov/historical-docs/19th-amendment>. Acesso em 15 de outubro de 2017.
} 
O movimento sufragista norte-americano exerceu grande influência no brasileiro. A líder Bertha Lutz, conforme se verá no capítulo três, participou de conferências feministas internacionais (algumas delas organizadas pela NAWSA) e conheceu lideranças americanas que influenciaram seu modo de pensar o sufrágio, principalmente Carrie Chapman Catt. A Federação Brasileira pelo Progresso Feminino, criada por Bertha Lutz, assim como a NAWSA, buscou se afastar da má reputação das sufragetes inglesas, cujas táticas radicais haviam repercutido negativamente perante a opinião pública.

Antes de iniciar a análise acerca do movimento sufragista no Brasil, entretanto, será apresentado um panorama da conquista do voto feminino em alguns países da América Latina, de modo a aprofundar um pouco mais a contextualização da luta brasileira internacionalmente.

\subsection{AMÉRICA LATINA}

O primeiro país da América Latina a reconhecer o voto feminino foi o Uruguai, mas apenas em âmbito local. As mulheres puderam votar pela primeira vez em 1927, em um plebiscito local da comunidade de Cerro Chato. Apenas em 1938 é que o sufrágio feminino foi aprovado a nível federal, quando o parlamento uruguaio aprovou lei que estabelecia o direito das mulheres de votarem e serem votadas. ${ }^{88}$ Por isso, muitos autores consideram que, na verdade, o primeiro país latino-americano a aprovar o voto feminino foi o Equador, que o fez em $1929 .{ }^{89}$

${ }_{88}$ SMINK, Veronica. 5 precursoras del voto femenino en América Latina. Disponível em $<$ http://www.bbc.com/mundo/noticias/2013/10/131018_100_mujeres_bastiones_feminismo_vs $>$. Acesso em 14 de outubro de 2017.

89 MARTÍNEZ, Laura Pellicer. El sufragio femenino en América Latina. Disponível em $<$ http://www.antrophistoria.com/2016/02/el-sufragio-femenino-en-america-latina.html $>$. Acesso em 14 de outubro de 2017. 
Um dos países latino-americanos que possuíam organização feminista mais significativa nas primeiras décadas do século XX foi a Argentina. Nesse período, houve um aumento considerável no número de mulheres no mercado de trabalho argentino, e muitas trabalhadoras vieram a aderir aos movimentos feministas anarquista e socialista, sobre os quais se falará brevemente mais adiante. Segundo a historiadora Asunción Lavrin, os anos de 1919 a 1932 foram os "anos dourados" do movimento feminista na Argentina. ${ }^{90}$

$\mathrm{O}$ início do século XX foi marcado pelo surgimento de grupos organizados voltados para a reivindicação de direitos de mulheres. A autora Gloria Bonilla Vélez cita alguns desses grupos, que aos poucos foram ganhando cada vez mais adesões: o Conselho Nacional de Mulheres, a União Gremial Feminina, o Centro Socialista Feminista, o Centro de Universitárias Argentinas, o Centro Feminista, a Liga para os Direitos da Mulher e da Criança e a Liga Feminista da República da Argentina. ${ }^{91}$

As estratégias utilizadas por tais grupos para fomentar as discussões ligadas a gênero incluíram, entre outras, a organização de congressos, a publicação de artigos em jornais e a elaboração de projetos que alterassem os marcos legais relativos a direitos civis e políticos. ${ }^{92}$ Vê-se que os métodos utilizados pelas argentinas eram muito similares àqueles empregados pelas sufragistas de outros países do mundo, como visto na Inglaterra e Estados Unidos e, conforme se verá no capítulo três, no Brasil, o que demonstra a semelhança dos movimentos sufragistas desses países.

O feminismo anarquista emergiu em Buenos Aires na década de 1890, ligado ao contexto da Argentina à época: rápido crescimento econômico,

\footnotetext{
${ }^{90}$ LAVRIN, Assunción. Mujeres y Feminismo en Argentina: 1900-1940. Revista Mujeres, Santiago de Chile, 1998, p. 34. Apud VÉLEZ, Gloria Estela Bonilla. La Lucha de Las Mujeres en América Latina: Feminismo, ciudadanía y derechos. Revista Palobra," palabra que obra", v. 8, n. 8, 2015. p. 43.

${ }_{91}^{91}$ VÉLEZ, Gloria Estela Bonilla. La Lucha de Las Mujeres en América Latina. p. 44.

92 VÉLEZ, Gloria Estela Bonilla. La Lucha de Las Mujeres en América Latina. p. 44.
} 
grande fluxo de imigrantes europeus e a formação de um movimento trabalhador ativo e radical. Preocupava-se com o poder exercido sobre as mulheres nas instituições do casamento e família, tendo como forte objetivo possibilitar que as mulheres se libertassem dessas instituições. ${ }^{93}$

De acordo com Bonilla Vélez, o anarquismo acabou perdendo espaço para o movimento socialista na Argentina, mais sensível aos pleitos da classe trabalhadora. Em 1894, foi fundado o Partido Socialista Argentino. Surge, assim, um novo feminismo, que buscava atender a demandas como melhores salários e condições de trabalho: o feminismo do Partido Socialista. Vale notar que, diferentemente dos anarquistas, os socialistas não fizeram uma crítica radical à instituição da família, ao machismo e ao autoritarismo. ${ }^{94}$

No século $\mathrm{XX}$, os debates acerca do sufrágio feminino foram intensificados. Enquanto algumas mulheres, como María Abella Ramírez e Julieta Lanteri, defendiam o direito ao voto feminino sem restrições, outras, como Alicia Moreau, entendiam que o voto deveria ser adquirido gradualmente: primeiro deveria ser exercido a nível local para depois ser alçado ao âmbito nacional. ${ }^{95}$ É interessante observar que a argumentação para a defesa do sufrágio feminino, nesse momento, fundava-se na dignidade das mulheres devido à condição de mães - ou seja, a maternidade era usada como estratégia para reivindicar a proteção dos direitos da mulher e a igualdade com os homens. Esse tipo de argumento foi utilizado também no Brasil, em que algumas sufragistas buscavam conseguir apoio dos homens afirmando que a participação política iria fazer com que as mulheres desempenhassem melhor suas atividades domésticas, como a educação dos filhos.

Nos anos 1920, verificou-se um crescimento da luta sufragista. Mulheres

\footnotetext{
${ }^{93}$ VÉLEZ, Gloria Estela Bonilla. La Lucha de Las Mujeres en América Latina. pp. 44 e 45.

${ }_{95}^{94}$ VÉLEZ, Gloria Estela Bonilla. La Lucha de Las Mujeres en América Latina. pp. 45 e 46.

${ }^{95}$ BARRANCOS, Dora. Los caminos del feminismo en la Argentina: historia y derivas. Voces en el Fénix, v. 32, 2014. pp. 8 e 9.
} 
de classe social mais elevada passaram a defender a causa, destacando-se Carmela Horne de Burmeister. Foram apresentados ao Congresso diversos projetos de lei conferindo direitos políticos às mulheres. Em 1932, a Câmara aprovou um projeto autorizando o voto feminino, que, contudo, não chegou a ser votado no Senado. ${ }^{96}$

Até meados da década de 1940, entretanto, houve certo enfraquecimento no ritmo das lutas feministas na Argentina. Dora Barrancos atribui tal fato à repercussão local dos avanços autoritários europeus. Acontecimentos como a Guerra Civil espanhola e o nazifascismo, que acarretaram um aumento do número de refugiados no país, fizeram com que a militância se voltasse, com maior empenho, para esses eventos.

Porém, com o advento do peronismo, a luta pelos direitos das mulheres voltou a ganhar força, tendo Eva Perón mobilizado grupos femininos e sindicatos. Em 1947, foi sancionada a lei do sufrágio. Em 1951, na primeira experiência do voto feminino na Argentina, as mulheres compareceram de forma massiva. ${ }^{97}$

No México, por sua vez, a incorporação das mulheres na Revolução de 1910 foi muito importante, não apenas nas tarefas "tradicionais" femininas (cozinhar, cuidar dos filhos), mas também em atividades militares. Mulheres foram espiãs, mensageiras, enfermeiras, colaboradoras nos planejamentos estratégicos. Após a Revolução Mexicana (1910-1917), renovou-se a arena política mexicana, e o feminismo adquiriu dimensão política.

A igualdade de direitos políticos foi um dos principais pleitos do movimento feminista mexicano, tendo três figuras obtido maior destaque: Hermilla Galindo, Elvia Carrillo e Refugio García. Em 1953, as mulheres

\footnotetext{
${ }^{96}$ BARRANCOS, Dora. Los caminos del feminismo en la Argentina. p. 9.

${ }^{97}$ BARRANCOS, Dora. Los caminos del feminismo en la Argentina. p. 9.
} 
mexicanas adquiriram plenos direitos políticos. ${ }^{98}$

O Panamá se tornou uma república independente com uma constituição bastante liberal para a época. A Constituição de 1904, além de admitir o sufrágio universal masculino, excluiu a referência expressa, presente na constituição colombiana, de que apenas os homens tinham direito a cidadania. Desde os primeiros anos do século XX, o Panamá recebeu influência direta de organizações femininas e do movimento feminista dos Estados Unidos. ${ }^{99}$

O debate sobre o sufrágio feminino ganha força no Panamá em 1922. Nesse ano, o deputado Pérez Venero apresentou projeto de lei dispondo sobre o voto feminino. Em dezembro do mesmo ano, foi criado o Grupo Feminista Renovación e foi anunciada a criação da Sociedad Nacional para el Progreso de la Mujer. ${ }^{100}$

Antes disso, em 1921, a Federación Obrera de Panamá incluiu em seu programa a reivindicação do sufrágio feminino. Todavia, nem todo o movimento operário era favorável ao voto feminino; uma parcela defendia que a mulher se tornaria competidora dos homens, o que colocaria em risco a causa da classe operária.

Em 1923, foi realizado o Primeiro Congresso Feminista Nacional e criado o Partido Nacional Feminista. Na década de 1940, o sufrágio feminino ganhou maior força e foi finalmente conquistado em 1946, com a aprovação da nova Constituição panamenha, que consagrava o direito a cidadania a todos os panamenhos maiores de vinte e um anos, sem distinção de sexo. ${ }^{101}$

A Colômbia, em sua Constituição de 1821, definia a qualidade de cidadão sem especificar o sexo. A partir da Constituição de 1843, que vigorou

\footnotetext{
${ }^{98}$ VÉLEZ, Gloria Estela Bonilla. La Lucha de Las Mujeres en América Latina. p. 48.

${ }^{99}$ VÉLEZ, Gloria Estela Bonilla. La Lucha de Las Mujeres en América Latina. pp. 48 e 49.

${ }^{100}$ VÉLEZ, Gloria Estela Bonilla. La Lucha de Las Mujeres en América Latina. p. 49.

${ }^{101}$ VÉLEZ, Gloria Estela Bonilla. La Lucha de Las Mujeres en América Latina. pp. 49 e 50.
} 
até meados do século XX, é que se introduziu expressamente a previsão de que cidadãos eram apenas os varões. ${ }^{102}$

A condição civil e jurídica da mulher colombiana era de total dependência em relação ao marido ou o pai. O Código Civil colombiano, assim como muitos códigos latino-americanos da época, estabelecia que a mulher devia obediência ao marido, perdendo a capacidade de administrar seu dinheiro e seus bens após o casamento. O marido detinha a administração exclusiva dos bens da sociedade conjugal e dos bens de propriedade da mulher. Os juristas colombianos, indo além, ampliaram em suas interpretações o direito do marido para inclusive permitir que ele inspecionasse as correspondências da mulher e lhe proibisse amizades que considerasse prejudiciais. ${ }^{103}$

Na década de 1920, muitas mulheres passaram a inserir nos debates públicos a questão do poder marital. Em 1932, foi aprovada uma lei que outorgava à mulher o direito de dispor livremente sobre seus bens, contrair dívidas e realizar outras transações financeiras. ${ }^{104}$ Mulheres como Georgina Fletcher e Ofelia Uribe de Acosta movimentaram os debates no Congresso, pressionando pelo direito das mulheres à educação. Em 1933, esse direito foi aprovado por meio de decreto e, em 1936, as mulheres adquiriram direito de ocupar cargos públicos. ${ }^{105}$

Em 1948, com o assassinato do chefe do Partido Liberal, Jorge Eliécer Gaitán, instaurou-se um período de revolta popular. Em meio a esse contexto de violência, o debate sobre o voto feminino continuou timidamente. Ofelia Uribe de Acosta e outras sufragistas continuaram se manifestando publicamente pelo sufrágio, e criaram o jornal La Verdad, escrito e

\footnotetext{
${ }^{102}$ VÉLEZ, Gloria Estela Bonilla. La Lucha de Las Mujeres en América Latina. p. 51.

${ }^{103}$ VÉLEZ, Gloria Estela Bonilla. La Lucha de Las Mujeres en América Latina. p. 52.

${ }^{104}$ VÉLEZ, Gloria Estela Bonilla. La Lucha de Las Mujeres en América Latina. p. 54.

${ }^{105}$ VÉLEZ, Gloria Estela Bonilla. La Lucha de Las Mujeres en América Latina. p. 54.
} 
administrado por mulheres. ${ }^{106}$

Apesar do contexto interno instável, a situação internacional era, de maneira geral, favorável ao voto para mulheres. Na América Latina, vários países, como o Brasil, já haviam aprovado o sufrágio feminino. Em 1954, foram nomeadas duas mulheres para a Assembleia Nacional Constituinte colombiana - Esmeralda Arboleda e Josefina Valencia - com o objetivo de que apresentassem um projeto de ato legislativo sobre a cidadania de mulheres. Esse ato, conferindo direitos políticos às mulheres colombianas, foi aprovado em 25 de agosto de $1954 .^{107}$

No Chile, a situação da mulher também era de dependência em relação ao homem, no início do século XX. Assim como em outros países da América Latina, ao casar, a mulher perdia a capacidade de dispor sobre seus bens e, caso trabalhasse, sobre seu salário. Em 1913, começaram a surgir os primeiros movimentos femininos organizados que buscavam melhorar a condição da mulher na sociedade. O principal pleito, à época, era o acesso à educação ainda que em 1877 o chamado Decreto Amunátegui (nomeado em virtude do então ministro da educação Miguel Luis Amunátegui) tenha conferido o direito de as mulheres ingressarem na Universidade, na prática, a educação continuava reservada aos homens. ${ }^{108}$

A Constituição chilena de 1833 , a rigor, não vedava expressamente o voto feminino, porém mulheres que tentaram votar nas eleições presidenciais de 1875 sob esse argumento foram impedidas de fazê-lo. Em 1884, foi editada uma lei eleitoral proibindo explicitamente o voto feminino. ${ }^{109}$

Em 1922, foi criado o Partido Cívico Feminino (PCF), que defendia o

\footnotetext{
${ }^{106}$ VÉLEZ, Gloria Estela Bonilla. La Lucha de Las Mujeres en América Latina. p. 55.

${ }^{107}$ VÉLEZ, Gloria Estela Bonilla. La Lucha de Las Mujeres en América Latina. p. 55.

${ }^{108}$ PARDO, Adolfo. Historia de la mujer en Chile: La conquista de sus derechos políticos en el siglo XX (1900-1952). Disponível em <http://critica.cl/historia/historia-de-la-mujer-en-chile-la-conquistalos-derechos-politicos-en-el-siglo-xx-1900-1952>. Acesso em 15 de outubro de 2017.

${ }^{109}$ PARDO, Adolfo. Historia de la mujer en Chile.
} 
voto feminino subordinado à educação, sob o mote "primero educar y luego decidir". ${ }^{110}$ As mulheres do PCF lutavam inicialmente pelo voto municipal, que seria uma espécie de ensaio para o voto em âmbito nacional. Em 1924, surgiu o Partido Democrata Feminino, que apresentou um projeto para alterar a lei eleitoral em vigor. ${ }^{111}$ Em 1933, foi formado o Comitê Nacional pelos Direitos da Mulher, para participar do debate acerca da lei de sufrágio municipal. Em 1934, durante o governo de Arturo Alessandri, foi editada lei outorgando à mulher o direito de votar e ser votada a nível municipal. ${ }^{112}$

Em 1935, foi criado o Movimento pela Emancipação da Mulher Chilena $(\mathrm{MEMCH})$ que defendia a proteção da mulher e da criança, a igualdade salarial entre mulheres e homens, além de debater temas como aborto clandestino, prostituição, divórcio, entre outros.

O presidente Pedro Aguirre Cerda, grande defensor dos direitos femininos, subiu ao poder em 1938. Pedro Cerda defendia que a Constituição chilena não vedava a participação política da mulher, e apresentou projeto de lei eleitoral que dispunha sobre o voto feminino. Em 1944, foi criada a Federação Chilena de Instituições Femininas (FECHIF), presidida por Amanda Labarca, que apresentou mais um projeto de lei sobre o voto da mulher.

Em 1948, a FECHIF lançou a famosa campanha "Queremos votar en las próximas elecciones". No mesmo ano, foi realizada uma assembleia com as lideranças de diversas organizações femininas, dando origem ao Comando Unido Nacional Pró Voto Feminino. No mesmo ano, foi aprovado pelo Congresso o projeto de lei conferindo direitos políticos às mulheres. Em janeiro de 1949, o presidente Gabriel González Videla sancionou o texto legal que outorgava plenos direitos políticos à mulher e, em 1952, as mulheres chilenas participam pela primeira vez na história do país de uma eleição

\footnotetext{
${ }^{110}$ PARDO, Adolfo. Historia de la mujer en Chile.

${ }^{111}$ PARDO, Adolfo. Historia de la mujer en Chile.

${ }^{112}$ PARDO, Adolfo. Historia de la mujer en Chile.
} 
presidencial. ${ }^{113}$

Esse relato da conquista do sufrágio feminino em alguns países da América Latina, ainda que breve, demonstra como o Brasil esteve adiantado nos debates sobre o assunto entre seus países vizinhos. Enquanto os autores situam o início das discussões feministas da maior parte dos países latinoamericanos nas primeiras décadas do século XX, veremos que, no Brasil, essa questão já foi suscitada no século XIX. A maior parte dos países latinoamericanos aprovou o sufrágio feminino no final da década de 1940 ou na década de 1950, enquanto o Brasil o fez no Código Eleitoral de 1932, atrás apenas do Equador, que reconheceu constitucionalmente o direito das mulheres ao voto em 1929.

${ }^{113}$ PARDO, Adolfo. Historia de la mujer en Chile. 


\section{A CONQUISTA DO SUFRÁGIO FEMININO NO BRASIL}

\subsection{PRIMEIRAS MANIFESTAÇÕES}

O Brasil é considerado pioneiro nas discussões pelo sufrágio feminino na América Latina ${ }^{114}$. Conforme levantou a pesquisadora uruguaia María Laura Osta Vázquez, ainda no Império foi elaborado um projeto de lei sobre direitos políticos das mulheres, datado de 1821, de autoria do deputado baiano Domingos Borges de Barros, apresentado nas Cortes de Lisboa. ${ }^{115}$ Segundo a pesquisadora, embora o projeto de lei em si não tenha sido encontrado em arquivos brasileiros ou portugueses, há referência a ele em três documentos: em um Parecer da Comissão de Legislação do Senado (de 12 de novembro de 1927); na obra "A reforma eleitoral" (1931), do jornalista Othelo Rosa; e em livro do próprio deputado, intitulado "Poesias oferecidas às mulheres brasileiras por um baiano" (1825). Assim, ainda que não tenhamos acesso ao conteúdo do projeto de lei, a partir desses documentos levantados por Osta Vázquez vemos que a discussão sobre direitos políticos e civis das mulheres já havia sido suscitada em 1821, mesmo que provocada por um homem.

Ao tratar do início do feminismo no Brasil, não se pode deixar de mencionar Nísia Floresta Brasileira Augusta (1809-1885), comumente referida como a primeira feminista brasileira. Nísia Floresta promoveu debates e conferências sobre temas como abolicionismo e república em 1842, o que já era algo extraordinário e avançado mesmo para homens. ${ }^{116}$ Em 1832, traduziu

\footnotetext{
114 BESTER, Gisela Maria. A Luta sufrágica feminina e a conquista do voto pelas mulheres brasileiras: aspectos históricos de uma caminhada. Argumenta Journal Law, n. 25, 2017. p. 334.

${ }^{115}$ OSTA VÁZQUEZ, María Laura. Discussões feministas no século XIX. Revista NUPEM, v. 6, n. 11, $2014 . \quad$ Disponível em http://www.fecilcam.br/revista/index.php/nupem/article/viewFile/547/324>. Acesso em 27 de outubro de 2017. p. 26.

${ }^{116}$ ALVES, Branca Moreira. Ideologia e feminismo. p. 87.
} 
o livro A Vindication of the Rights of Woman, escrito pela inglesa Mary Wollstonecraft, considerado um referencial do feminismo moderno, com o título Direitos das mulheres e injustiças dos homens.

De acordo com a autora Branca Moreira Alves, a maior contribuição de Nísia Floresta foi no que diz respeito à luta pela educação da mulher. Criticava fortemente a situação de dependência das mulheres em relação aos homens, resultante, principalmente, da ignorância em que eram mantidas as meninas. ${ }^{117}$ Nísia fundou e dirigiu colégios femininos, de modo a investir nas suas ideias de emancipação feminina através da educação. ${ }^{118}$

$\mathrm{Na}$ segunda metade do século XIX, outras mulheres pioneiras demonstravam insatisfação com os moldes da vida social e política no Brasil, em que elas eram deixadas à margem das discussões públicas. Tal insatisfação era expressada principalmente em jornais editados por elas, por meio dos quais pretendiam alcançar outras mulheres da sociedade, incentivando-as a elevar suas ambições e desejos. ${ }^{119}$ Segundo a historiadora americana June E. Hahner, que se dedicou a estudar a história das mulheres na América Latina, essas primeiras feministas

Tentaram incitar mudanças no status econômico, social e legal das mulheres no Brasil. Confiantes no progresso, buscaram inspiração e promessas de sucessos futuros nas realizações de mulheres em outros países. Bastante conscientes da oposição masculina, e da indiferença feminina, e da aceitação limitada de suas próprias ideias, essas mulheres corajosas se mantiveram convencidas da importância de sua causa e de seu sucesso futuro. ${ }^{120}$

À época, o maior pleito defendido pelas editoras desses jornais feministas era a educação para as mulheres, entendendo que a educação e instrução eram fundamentais para a emancipação feminina. Além disso, elas também defendiam a inserção feminina no mundo do trabalho, por meio da abertura de

\footnotetext{
${ }^{117}$ ALVES, Branca Moreira. Ideologia e feminismo. pp. 88 e 89.

${ }^{118}$ ALVES, Branca Moreira. Ideologia e feminismo. p. 89

${ }^{119}$ HAHNER, June E. A mulher brasileira e suas lutas sociais e políticas: 1850-1937. São Paulo: editora Brasiliense, 1981. p. 25.

${ }^{120}$ HAHNER, June E. A mulher brasileira e suas lutas sociais e politicas. pp. 25 e 26.
} 
todas as carreiras às mulheres. Argumentava-se que a submissão feminina se devia em grande parte à dependência econômica em relação aos homens e, portanto, a possibilidade de as mulheres trabalharem contribuiria muito para mudar essa situação.

Em seus jornais na década de 1870, essas feministas não haviam defendido o voto da mulher. Alguns dos periódicos simplesmente não mencionavam o assunto, enquanto outros chegavam a se mostrar expressamente contrários à participação feminina na vida política. ${ }^{121}$

Entretanto, no final da década de 1880, com os ideais republicanos se espalhando pelo Brasil, algumas feministas passaram a exigir publicamente o voto feminino, entendido como mais uma forma de expressão da igualdade de direitos no exercício da cidadania. Assim, o desejo das mulheres por direitos políticos foi se fortalecendo. Por exemplo, o jornal $O$ Sexo Feminino, publicado em Minas Gerais pela professora Francisca Senhorinha da Motta Diniz, passou a dedicar uma coluna exclusivamente à questão do sufrágio feminino após a proclamação da República. Conforme ensina Hahner,

A "emancipação da mulher" estava adquirindo um significado cada vez mais vasto. No final do século XIX, algumas mulheres não mais queriam apenas respeito, tratamento favorável dentro da família ou direito à educação, mesmo educação universitária, mas sim o desenvolvimento pleno de todas as suas faculdades, dentro e fora do lar. (...) elas visualizavam as mulheres trabalhando em pé de igualdade com os homens em todas as esferas, a ocupar "todos os cargos, desempenhar todas as funções; em tudo devemos competir com os homens - no governo da família, como na direção do estado". Vinculavam a causa pelo sufrágio à igualdade da mulher e aos direitos humanos gerais. $^{122}$

\subsection{ASSEMBLEIA CONSTITUINTE E CONSTITUIÇÃO DE 1891}

Na Assembleia Constituinte de 1891, foi intensamente debatida a questão

\footnotetext{
${ }^{121}$ HAHNER, June E. A mulher brasileira e suas lutas sociais e politicas. p. 78.

${ }^{122}$ HAHNER, June E. A mulher brasileira e suas lutas sociais e políticas. p. 81.
} 
do sufrágio feminino. No projeto do Governo Provisório, elaborado por uma comissão composta por cinco membros - Antônio Luís dos Santos Werneck, Américo Brasiliense de Almeida Mello, José Antônio Pedreira de Magalhães Castro, Rangel Pestana e Saldanha Marinho -, inicialmente não havia previsão do voto feminino. Porém, na chamada "Comissão dos 21 ", formada por um representante de cada estado e do Distrito Federal, Lopes Trovão, Leopoldo de Bulhões e Casimiro Júnior apresentaram proposta de sufrágio "às mulheres diplomadas com títulos científicos e de professora, desde que não estivessem sob o poder marital nem paterno, bem como às que estivessem na posse de seus bens". ${ }^{123}$

Walter Costa Porto, ex-ministro do Tribunal Superior Eleitoral, em seu livro O Voto no Brasil, citou os defensores do voto feminino nos anais da Constituinte de 1891. Além dos já mencionados Lopes Trovão, Leopoldo de Bulhões e Casimiro Júnior, também foram a favor os constituintes Sá Andrade e César Zama, que propuseram que o sufrágio fosse dado "às cidadãs solteiras ou viúvas, diplomadas em direito, medicina ou farmácia e às que dirigissem estabelecimentos docentes, industriais ou comerciais". ${ }^{124}$ Ainda, foi proposta, por vinte e oito constituintes, uma emenda ao projeto de Constituição para conferir o direito ao voto às mulheres "diplomadas com títulos científicos e de professoras, às que estivessem na posse de seus bens e às casadas". ${ }^{125}$

Como se pode notar, os constituintes que defendiam o sufrágio feminino apoiavam a concessão do direito de voto apenas a determinadas mulheres e sempre de forma condicionada, principalmente à profissão e/ou ao estado civil, mas não de forma ampla.

Não obstante, o sufrágio feminino encontrou fortes adversários na

\footnotetext{
${ }^{123}$ PORTO, Walter Costa. O voto no Brasil: da Colônia à $6^{\text {a }}$ República. $2^{\mathrm{a}}$ ed. rev. Rio de Janeiro: Topbooks, 2002. p. 159.

${ }^{124}$ PORTO, Walter Costa. O voto no Brasil. p. 233.

${ }^{125}$ PORTO, Walter Costa. O Voto no Brasil. p. 233.
} 
Constituinte. Muniz Freire entendia ser uma ideia imoral e anárquica, que poria em risco a família brasileira. Lauro Sodré afirmou que a ideia era "anárquica, desastrada, fatal", "filha de uma democracia revolucionária, metafísica e irrefletida" 126 , enquanto Tito Lívio defendeu que as mulheres tinham "cérebros infantis" e eram portadoras de "inferioridade mental" e "retardo evolutivo". ${ }^{127}$

Muitos congressistas opositores ao voto feminino baseavam sua argumentação na "moral", que seria um atributo exclusivo do sexo feminino. A superioridade moral da mulher seria incompatível com a vida política. Nesse sentido, Muniz Freire afirmou:

essa aspiração se me afigura imoral e anárquica, porque, no dia em que a convertêssemos em lei pelo voto do Congresso, teríamos decretado a dissolução da família brasileira (...). Ora, querer desviar o espírito feminil desse dever (...) que é a base de toda a organização social, cujo primeiro grão é a família (...), é nulificar esses laços sagrados (...), que se formam em torno da vida puramente doméstica da mulher, e corromper a fonte preciosa da moralidade e da sociabilidade (...), demandando como condição de pureza, sua abstenção completa da vida prática. ${ }^{128}$

Conforme analisou Osta Vázquez, as mulheres adquiriam a "moral" simplesmente por nascerem com o sexo feminino e, por serem as "guardiãs da moral”, sua única função seria dedicar-se ao lar e à educação dos filhos, já que qualquer distração poderia destruir essa "moral". Ainda de acordo com Osta Vázquez, esse pronunciamento do congressista revela a forma como a mulher era vista pela sociedade da época: às mulheres cabiam as emoções e afeto, enquanto a inteligência e a vida ativa ficavam com os homens. ${ }^{129}$

Um forte argumento para aqueles contrários ao voto feminino era que outros países do mundo também não o haviam permitido. A falta de precedentes estrangeiros não conseguiu ser superada pelos defensores do sufrágio feminino.

\footnotetext{
${ }^{126}$ PORTO, Walter Costa. O voto no Brasil. p. 233.

${ }^{127}$ BUONICORE, Augusto C. As mulheres e os direitos politicos no Brasil. In: NAZARIO, Diva Nolf. Voto feminino e feminismo. São Paulo: Imprensa Oficial do Estado de São Paulo, 2009. p. 196.

${ }^{128}$ Annaes do Congresso Constituinte da República, 1990, p. 439. Apud OSTA VÁZQUEZ, María Laura. Discussões feministas no século XIX. p. 28.

${ }^{129}$ OSTA VÁZQUEZ, María Laura. Discussões feministas no século XIX. pp. 28 e 29.
} 
Assim, eleitores, na Constituição de 1891, eram os cidadãos maiores de vinte e um anos que se alistassem na forma da lei (artigo 70). Considerando que foram recusadas todas as emendas concessivas de voto à mulher, muitos interpretaram que as mulheres estavam excluídas da condição de eleitoras, não podendo votar, embora a proibição do voto feminino não estivesse expressa no texto constitucional.

\subsection{AS SUFRAGISTAS NO SÉCULO XX}

No início do século $\mathrm{XX}$, o feminismo foi aos poucos conseguindo mais defensores e deixando de ser motivo de escárnio, para uns, e de ousadia desmedida, para outros. Segundo Hahner, uma escritora portuguesa que contribuía para os jornais feministas brasileiros, Maria Amélia Vaz de Carvalho, apontou, à época, que "o feminismo não mais era déclassé". 130

Os movimentos que defendiam os direitos da mulher foram ganhando força em outros países e as elites brasileiras foram começando a apoiar tais movimentos. Mais e mais mulheres das classes média e superior reivindicavam os mesmos direitos dos homens, principalmente o acesso aos cargos profissionais e ao voto. Esses pleitos eram considerados socialmente aceitáveis. $^{131}$

Na década de 1910, Myrthes de Campos, a primeira mulher a ser aceita no Instituto da Ordem dos Advogados, requereu seu alistamento eleitoral, com fundamento no fato de que a Constituição de 1891 não vedava o voto feminino. Porém, seu pedido foi indeferido. ${ }^{132}$ Segundo informações levantadas por Branca Moreira Alves, três mulheres conseguiram se alistar e

\footnotetext{
${ }^{130}$ HAHNER, June E. A mulher brasileira e suas lutas sociais e politicas. p. 92.

${ }^{131}$ HAHNER, June E. A mulher brasileira e suas lutas sociais e politicas. p. 94.

${ }^{132}$ ALVES, Branca Moreira. Ideologia e feminismo. pp. 94 e 95.
} 
votar já em 1905, na comarca de Minas Novas, em Minas Gerais. São elas: Alzira Vieira Ferreira Neto, Cândida Maria dos Santos e Clotilde Francisca de Oliveira. ${ }^{133}$

Em 1910, foi fundado o Partido Republicano Feminino (PRF), presidido por Leolinda de Figueiredo Daltro. Leolinda Daltro, professora, se dirigia principalmente a outras professoras e a mulheres de classe média, e tinha como um de seus principais pleitos que os cargos públicos fossem abertos a todos os brasileiros, independentemente de sexo. ${ }^{134}$ Ela foi extremamente importante nos primeiros passos para um movimento feminista organizado no Brasil e para que a discussão sobre a emancipação feminina fosse difundida mais amplamente na sociedade.

O fato de o Partido Republicano Feminino ser composto tão somente por mulheres, sendo expressamente vedada a participação de homens, já revela a ruptura trazida por Leolinda Daltro: era um partido político composto exclusivamente por pessoas que não tinham direitos políticos. ${ }^{135}$ Dentre os objetivos previstos no estatuto do partido, estava "Pugnar para que sejam consideradas extensivas às mulheres as disposições constitucionais da República dos Estados Unidos do Brasil, desse modo incorporando-a na sociedade brasileira". 136

Leolinda sofreu fortes críticas e foi alvo de ridicularização por parte da imprensa da época. Em 1913, jornais brasileiros noticiavam o movimento sufragista inglês, enfatizando a violência do movimento (incêndios, quebras de vidraças, ataques aos políticos) e o colocando como um exemplo a não ser seguido. Leolinda passou a ser chamada de Miss Pankhurst brasileira pela

\footnotetext{
${ }^{133}$ ALVES, Branca Moreira. Ideologia e feminismo. p. 95.

${ }^{134}$ HAHNER, June E. A mulher brasileira e suas lutas sociais e politicas. p. 94.

135 KARAWEJCZYK, Mônica. Os primórdios do movimento sufragista no Brasil: o feminismo "pátrio" de Leolinda Figueiredo Daltro. Estudos Ibero-Americanos, v. 40, n. 1, 2014. p. 71.

${ }^{136}$ Diário Oficial, 17 de dezembro de 1910, p. 47. Apud KARAWEJCZYK, Mônica. Os primórdios do movimento sufragista no Brasil. p. 72.
} 
imprensa, que a associava à líder sufragista inglesa Emmeline Pankhurst. ${ }^{137}$

Segundo a historiadora Mônica Karawejczyk, em 1917, três clubes carnavalescos "homenagearam" Leolinda no Carnaval de rua do Rio de Janeiro. Os clubes Democráticos, os Tenentes do Diabo e os Fenianos, em seus desfiles, incluíram referência ou ao sufrágio feminino ou à própria Leolinda. ${ }^{138}$ Embora tenham sido referências jocosas, demonstram como o nome de Leolinda era conhecido pela sociedade e também como sua luta incomodava.

Na década de 1920, a defesa do voto para mulheres (desde que de forma moderada) começou a se tornar socialmente aceitável no Brasil e até mesmo quase elegante entre a elite brasileira. ${ }^{139}$ Foram-se formando organizações para defender os direitos das mulheres. Entretanto, como nota Hahner, com a ampliação do apelo de tais movimentos entre as classes superiores, os movimentos feministas tornaram-se mais conservadores.

No século XX, portanto, o movimento sufragista se fortaleceu, tendo algumas mulheres profissionais se estabelecido como liderança. Cabe citar, aqui, Bertha Lutz, bióloga e ativista política brasileira que se tornou a líder do movimento sufragista feminino no Brasil. Nas décadas de 1920 e 1930, tal movimento já incluía mulheres de diversas profissões, como advogadas, médicas e engenheiras.

Contudo, alguns historiadores, como Hahner, consideram que as mudanças defendidas por essas sufragistas, vinculadas à elite brasileira, eram menos drásticas com relação à alteração dos papeis tradicionalmente impostos às mulheres do que aquelas defendidas por algumas feministas no final do século XIX. Como exemplo desta afirmação podemos citar o periódico Nosso Jornal, fundado por Cassilda Martins e Júlia Lopes de Almeida em 1919, que,

\footnotetext{
${ }^{137}$ KARAWEJCZYK, Mônica. Os primórdios do movimento sufragista no Brasil. p. 74.

${ }^{138}$ KARAWEJCZYK, Mônica. Os primórdios do movimento sufragista no Brasil. p. 76.

${ }^{139}$ HAHNER, June E. A mulher brasileira e suas lutas sociais e politicas. p. 96.
} 
apesar de apoiar o voto feminino, não defendia uma ruptura com a ordem anterior, mas sim a busca de um equilíbrio:

Embora o Nosso Jornal louvasse muitas das oportunidades abertas às brasileiras e fosse favorável ao sufrágio feminino, procurava a harmonia entre o novo e o velho. Nosso Jornal opunha-se ao "feminismo radical" encontrado em outros países, que iria subverter os "moldes clássicos da existência da mulher". Como a maioria da imprensa comum, essas mulheres expressavam orgulho por um movimento feminista brasileiro que alcançasse seus objetivos sem a violência e a hostilidade antimachista vista nos Estados Unidos na Inglaterra, e elas se sentiam superiores à suffragette inglesa atiradora de bombas, "agressiva e intolerante". ${ }^{140}$

Em 1918, Bertha Lutz publicou um artigo em que convocava mulheres para a formação de uma organização para a defesa dos direitos das mulheres, incluindo o direito ao voto. Em 1920, juntamente com Maria Lacerda de Moura, Bertha Lutz fundou a Liga para a Emancipação Intelectual da Mulher, voltada para a luta por igualdade política para as mulheres:

Em várias entrevistas para jornais, Bertha Lutz expandia-se sobre os objetivos do movimento. Estes iam desde interesses altamente generalizados, como a paz mundial, até assuntos específicos, como o pagamento igual para trabalho igual e oportunidades educacionais iguais. Mas, para realizar esses objetivos, afirmava, as mulheres precisavam ter acesso ao processo político como cidadãs plenas e iguais; precisavam ter participação política direta e legítima. Bertha Lutz e outras sufragistas viam o voto "como meio de ação", como um instrumento para superar as barreiras em direção a uma sociedade liberal mais completa. Serviria como o instrumento necessário para o progresso e não meramente como um fim em si mesmo. ${ }^{141}$

Dessa forma, o voto era considerado um instrumento fundamental para o exercício da cidadania pelas mulheres. A igualdade de direitos - seja o direito ao acesso à educação e aos cargos profissionais, seja o direto de receber salário igual aos homens, etc. - somente seria possível mediante participação política ampla. Ou seja, o voto, como coloca Hahner, não era encarado como um fim em si mesmo, mas sim como um meio para a conquista de direitos pelas mulheres.

No mesmo sentido, escreveu Zina Abreu que

\footnotetext{
${ }^{140}$ HAHNER, June E. A mulher brasileira e suas lutas sociais e politicas. pp. 100 e 101.

${ }^{141}$ HAHNER, June E. A mulher brasileira e suas lutas sociais e políticas. p. 103.
} 
as sufragistas argumentavam que as vidas das mulheres não melhorariam até que os políticos tivessem que prestar contas a um eleitorado feminino. Acreditavam que as muitas desigualdades legais, econômicas e educacionais com que se confrontavam jamais seriam corrigidas, enquanto não tivessem o direito de voto. A luta pelo direito de voto era, portanto, um meio para atingir um fim. ${ }^{142}$

Aos poucos, o movimento pelo sufrágio feminino no Brasil foi construindo vínculos com movimentos e organizações sufragistas de outros países, principalmente por meio da líder Bertha Lutz.

Como visto, o movimento sufragista americano se preocupava com a posição da mulher em outros países do mundo. A feminista americana Susan B. Anthony havia liderado a fundação do Conselho Internacional de Mulheres, em 1888, voltado para promover o avanço da condição da mulher na sociedade. Ainda que o Conselho não fosse uma associação sufragista, denota o interesse norte-americano em articular discussões sobre feminismo internacionalmente.

Em 1919, Bertha Lutz representou o Brasil, juntamente com Olga de Paiva Meira, na reunião do Conselho Feminino da Organização Internacional do Trabalho, na qual foi aprovado o princípio de salário igual para trabalho igual. ${ }^{143}$ Em 1922, Bertha Lutz participou da primeira Conferência PanAmericana de Mulheres, ocorrida em Baltimore, Estados Unidos. Ao fim de tal Conferência, as representantes latino-americanas formaram a Associação PanAmericana de Mulheres. Definiram que em cada país da América Latina haveria uma Associação Nacional e associações estaduais, conforme aplicável.

Nos EUA, Bertha Lutz conheceu Carrie Chapman Catt, uma das lideranças do movimento sufragista norte-americano. Catt fazia parte de uma corrente menos radical do feminismo, diferentemente das sufragistas europeias, cujo movimento era mais violento. As ideias de Catt foram bem

\footnotetext{
${ }^{142}$ ABREU, Zina Abreu. Luta das mulheres pelo direito de voto. p. 460.

${ }^{143}$ BUONICORE, Augusto C. As mulheres e os direitos politicos no Brasil. In: NAZARIO, Diva Nolf. Voto feminino e feminismo. p. 198.
} 
recebidas por Bertha Lutz, que, em entrevista,

afirmou que a orientação da senhora Carrie era "muito salutar, pois o movimento nos Estados Unidos tem sido muito digno e completamente alheio aos métodos violentos empregados por alguns países europeus". Esses métodos pacíficos se adequavam mais à condição social das feministas brasileiras daquele tempo. ${ }^{144}$

Nesse período, foram criadas diversas organizações no Brasil voltadas para a luta feminista. Em 1922, Bertha fundou, substituindo a Liga pela Emancipação Intelectual da Mulher, a Federação Brasileira pelo Progresso Feminino (FBPF), a primeira organização feminista brasileira com expressão nacional e internacional. ${ }^{145} \mathrm{O}$ estatuto da FBPF previa como objetivos da Federação, dentre outros, "assegurar à mulher os direitos políticos que a nossa Constituição the confere e prepará-la para o exercício inteligente desses direitos" e "estreitar os laços de amizade com os demais países americanos, a fim de garantir a manutenção perpétua da Paz e da Justiça no Hemisfério Ocidental". ${ }^{146}$

A Federação Brasileira pelo Progresso Feminino organizou a primeira conferência brasileira de mulheres, no Rio de Janeiro, que contou com a presença da sufragista Carrie Chapman Catt, em dezembro de 1922. Acatando o conselho de Catt, participaram da mesa alguns políticos de destaque, o que, segundo Catt, conferiria maior importância ao congresso. Assim, participaram o vice-presidente da República, Estácio Coimbra, o senador Lopes Gonçalves e o senador Lauro Muller, que defenderam a constitucionalidade do voto feminino.

Foi inaugurada a Aliança Brasileira pelo Sufrágio Feminino, cuja secretária-geral era Bertha Lutz. Em São Paulo, a escritora Diva Nolf Nazario e a advogada Walkyria Moreira da Silva formaram uma associação sufragista

\footnotetext{
${ }^{144}$ BUONICORE, Augusto C. As mulheres e os direitos politicos no Brasil. In: NAZARIO, Diva Nolf. Voto feminino e feminismo.pp. 198 e 199.

${ }^{145}$ BUONICORE, Augusto C. As mulheres e os direitos políticos no Brasil. In: NAZARIO, Diva Nolf. Voto feminino e feminismo. p. 199.

${ }^{146}$ HAHNER, June E. A mulher brasileira e suas lutas sociais e políticas. p. 107.
} 
própria, filiada à Aliança Brasileira pelo Sufrágio Feminino. ${ }^{147}$

Ao longo da década de 1920, as sufragistas brasileiras continuaram lutando pelos direitos políticos das mulheres, empregando as táticas, características do movimento, de influenciar a opinião pública e fazer pressão sobre os membros do Congresso. ${ }^{148} \mathrm{O}$ uso da publicidade e da imprensa era uma forma eficiente de alcançar a sociedade - assim, as líderes sufragistas frequentemente concediam entrevistas, nas quais argumentavam por sua causa de modo a mobilizar as opiniões sociais. ${ }^{149}$ Além disso, elas também trabalhavam as relações pessoais com políticos influentes, aproveitando-se de relações de amizade entre seus familiares e parlamentares, para ganhar o seu apoio no movimento e avançar o debate pela causa sufragista. ${ }^{150}$

Bertha Lutz, durante os anos 20, continuou participando de conferências feministas internacionais. Representou oficialmente o Brasil no $9^{\circ}$ Congresso da Aliança Internacional pelo Sufrágio Feminino, realizado em Roma em 1923, e no Congresso Interamericano de 1925, ocorrido em Washington.

No entanto, é importante observar que as líderes sufragistas brasileiras não buscavam uma reestruturação radical da sociedade ou de seu sistema político. Seus discursos possuíam tom moderado. Argumentavam, face aos receios dos anti-sufragistas de que o sufrágio feminino poria em risco o destino da família brasileira, que os direitos políticos da mulher não ameaçariam a vida doméstica e nem lhes tomariam muito tempo. Como observou Hahner,

Assim como argumentavam que o status biológico da mulher não deveria ter nenhum efeito sobre sua capacidade em ações de caráter político, também aceitavam sem questionar - exatamente como faziam os partidários masculinos do sufrágio feminino a definição básica da esfera de interesses da mulher como girando em torno do lar; da

\footnotetext{
${ }^{147}$ HAHNER, June E. A mulher brasileira e suas lutas sociais e politicas. p. 108.

${ }^{148}$ SOIHET, Rachel. A pedagogia da conquista do espaço público pelas mulheres e a militância feminista de Bertha Lutz. Disponível em < http://www.scielo.br/pdf/rbedu/n15/n15a07>. Acesso em 27 de outubro de 2017. p. 101.

${ }^{149}$ HAHNER, June E. A mulher brasileira e suas lutas sociais e políticas. pp. 113 e 114.

${ }^{150}$ SOIHET, Rachel. A pedagogia da conquista do espaço público pelas mulheres e a militância feminista de Bertha Lutz. p. 101.
} 
família e de assuntos relativos à educação, à saúde e ao bem-estar. O que fizeram foi redefinir o lar para incluir novas e mais vastas áreas de interesse. ${ }^{151}$

Com essa "redefinição" do conceito de lar, este passaria a englobar os locais de trabalho, pois neles as mulheres ganham dinheiro para alimentar os filhos, e os ambientes legislativos, nos quais são discutidas leis de proteção aos filhos. ${ }^{152}$ Isto é, as sufragistas não pugnavam para que a vida da mulher deixasse de ser voltada para a família, mas defendiam um alargamento da zona de abrangência dos interesses da família.

Assim, não podemos afirmar que as líderes sufragistas desejavam uma ruptura com o sistema vigente. Concordavam que as mulheres tinham um dever para com o lar e a vida doméstica, e buscavam confortar os homens afirmando que os direitos políticos não só não alterariam esse quadro, como na verdade fariam com que a mulher ficasse melhor informada e pudesse atender melhor os seus deveres familiares. ${ }^{153}$

Talvez isso se deva a razões estratégicas: para não arriscar a consecução do almejado sufrágio, buscaram limitar seu pleito a essa questão, em vez de defender maiores mudanças com o sistema. Outra explicação é que uma alteração social radical não interessava às líderes sufragistas que pertenciam às classes superiores.

Porém, cumpre salientar que as organizações sufragistas mencionadas neste capítulo não esgotavam a luta por direitos femininos da época. Havia, por exemplo, movimentos de resistência negra, contando com a participação de mulheres, que reivindicavam uma efetiva inserção social e maior participação política dos negros, além de lideranças femininas negras que também lutavam pelos direitos das mulheres.

Uma das maiores organizações de resistência negra no século XX foi a

\footnotetext{
${ }^{151}$ HAHNER, June E. A mulher brasileira e suas lutas sociais e políticas. pp. 115 e 116.

${ }^{152}$ HAHNER, June E. A mulher brasileira e suas lutas sociais e politicas. p. 116.

${ }^{153}$ ALVES, Branca Moreira. Ideologia e feminismo. p. 106.
} 
Frente Negra Brasileira (FNB), fundada em 1931 em São Paulo. A FNB possuía um projeto antirracista visando à integração do negro, como cidadão, na sociedade. ${ }^{154}$ Segundo o Estatuto da FNB, tratava-se de uma "união política e social da Gente Negra Nacional, para afirmação dos direitos históricos da mesma (...) e para a reivindicação de seus direitos sociais e políticos, atuais, na Comunhão Brasileira"155. O Estatuto estabelecia que, como forma de alcançar os seus fins sociais, a FNB pleitearia "dentro da ordem legal instituída no Brasil, os cargos eletivos de representação da Gente Negra Brasileira, efetivando sua ação político-social em sentido rigorosamente brasileiro". ${ }^{156}$

A entidade possuía filiais distribuídas em outros Estados além de São Paulo, como o Rio de Janeiro, Minas Gerais e Espírito Santo ${ }^{157}$, e criou um jornal, intitulado $A$ Voz da Raça, para divulgar os seus ideais. ${ }^{158}$ Muitas mulheres negras se associaram à FNB, sendo que a atuação das mulheres foi considerada pelos próprios líderes da Frente como essencial para manter a união dos associados. ${ }^{159}$

Foram criados dois departamentos femininos dentro da FNB: as Rosas Negras (comissão responsável por organizar saraus, festivais e bailes) e a Cruzada Feminina (cujo objetivo era fortalecer o campo educacional e cultural da FNB $)^{160}$. As atividades recreativas promovidas pelas Rosas Negras eram importantes para a manutenção da coesão da associação, enquanto a parte educacional e cultural era fundamental para a consecução dos objetivos sociais da FNB, que incluíam a elevação intelectual, técnica e profissional da

\footnotetext{
${ }^{154}$ DOMINGUES, Petrônio. Frentenegrinas: notas de um capítulo da participação feminina na história da luta anti-racista no Brasil. cadernos pagu, n. 28, 2007. Disponível em < http://www.scielo.br/pdf/cpa/n28/15>. Acesso em 5 de novembro de 2017. p. 351.

${ }_{155}$ Diário Oficial do Estado de São Paulo, 04/11/1931:12. Apud DOMINGUES, Petrônio. Frentenegrinas. p. 351.

156 Diário Oficial do Estado de São Paulo, 04/11/1931:12. Apud DOMINGUES, Petrônio. Frentenegrinas. p. 351.

${ }^{157}$ DOMINGUES, Petrônio. Frentenegrinas. p. 352.

${ }^{158}$ DOMINGUES, Petrônio. Frentenegrinas. p. 353.

${ }^{159}$ DOMINGUES, Petrônio. Frentenegrinas. p. 370.

${ }^{160}$ DOMINGUES, Petrônio. Frentenegrinas. pp. 360 e 362.
} 
população negra (conforme artigo $3^{\circ}$ do Estatuto) ${ }^{161}$.

No entanto, conforme ressalta Petrônio Domingues ${ }^{162}$, as mulheres frentenegrinas ocupavam posições consideradas secundárias na $\mathrm{FNB}$, não integrando as instâncias decisórias, as quais eram monopolizadas pelos homens. De qualquer forma, as mulheres participavam ativamente da associação, o que demonstra sua conscientização sobre seus direitos como cidadãs brasileiras e sua luta por mudanças na ordem social da época.

Além disso, não se pode deixar de mencionar algumas mulheres que, nas primeiras décadas do século $\mathrm{XX}$, também defenderam o direito ao voto feminino, bem como se preocupavam com a posição da mulher e dos negros na sociedade, como é o caso de Antonieta de Barros (ou Maria da Ilha) e Almerinda Gama.

Antonieta de Barros, nascida em 1901, foi uma educadora e jornalista brasileira. Fundou e dirigiu o Curso Particular Antonieta Barros e trabalhou como cronista em jornais na década de 1920 , tendo criado o periódico $A$ Semana. ${ }^{163}$ Utilizando o pseudônimo Maria da Ilha, escreveu o livro Farrapos de Ideias.

Antonieta foi uma forte defensora do sufrágio feminino e há registros de correspondências trocadas com Bertha Lutz a respeito desse tema durante os anos $1930 .{ }^{164}$ Sobre o voto feminino, escreveu em um de seus textos:

Que seremos nós, as mulheres? Irracionais ou domesticadas? Porque esta questão de inteligência e aptidões femininas, ora em foco, se resume, digamos de passagem, em classificar a mulher entre as criaturas superiores ou entre os irracionais (...). Inferior aos próprios irracionais, doméstica e domesticada, se contentará, eternamente em

161 Diário Oficial do Estado de São Paulo, 04/11/1931:12. Apud DOMINGUES, Petrônio. Frentenegrinas. p. 351.

${ }^{162}$ DOMINGUES, Petrônio. Frentenegrinas. p. 358.

${ }^{163}$ BRAZIL, Érico Vital e SCHUMAHER, Schuma (org.). Dicionário Mulheres do Brasil: de 1500 até a atualidade. $2^{\text {a }}$ edição. Rio de Janeiro: Jorge Zahar. p. 101.

${ }^{164}$ BRAZIL, Érico Vital e SCHUMAHER, Schuma (org.). Dicionário Mulheres do Brasil. p. 101. 
constituir a mais sacrificada metade do gênero humano ${ }^{165}$

Antonieta de Barros foi a primeira mulher negra a assumir um mandato popular no Brasil, tendo sido eleita para o cargo de deputada estadual de Santa Catarina em 1934. ${ }^{166}$

Almerinda Gama, nascida em 1899 no Alagoas, foi, também, uma das primeiras mulheres negras a atuar na política no Brasil. ${ }^{167}$ Em 1929, mudou-se para o Rio de Janeiro, onde se tornou uma importante líder sindical, presidente do Sindicato dos Datilógrafos e Taquígrafos.

Almerinda apoiou publicamente as ações de Bertha Lutz na defesa do sufrágio feminino. Na eleição de representantes para a Assembleia Constituinte de 1933, em que o voto feminino já era permitido, foi a única mulher a votar como delegada na eleição de representantes classistas. ${ }^{168}$

Dessa forma, ainda que as organizações sufragistas brasileiras de maior peso, como a Federação Brasileira pelo Progresso Feminino, não buscassem uma alteração na ordem social vigente, isso não significa que outras feministas não o fizeram. Antonieta de Barros, dedicada à educação da população carente, e Almerinda Gama, líder sindical, ambas defensoras do sufrágio feminino, bem como as mulheres filiadas à Frente Negra Brasileira, nos mostram que havia outros grupos de mulheres que reivindicavam espaço político e que também colocavam a questão social e racial em foco.

\subsection{LEGISLAÇÃO INFRACONSTITUCIONAL E ALGUMAS DECISÕES JUDICIAIS}

165 FALCARI, Gisele. Antonieta de Barros: protagonista de uma história. Disponível em < https://www.geledes.org.br/antonieta-de-barros-protagonista-de-uma-mudanca/ $>$. Acesso em $5 \mathrm{de}$ novembro de 2017.

${ }^{166}$ BRAZIL, Érico Vital e SCHUMAHER, Schuma (org.). Dicionário Mulheres do Brasil. p. 101.

${ }^{167}$ BRAZIL, Érico Vital e SCHUMAHER, Schuma (org.). Dicionário Mulheres do Brasil. p. 43.

${ }^{168}$ BRAZIL, Érico Vital e SCHUMAHER, Schuma (org.). Dicionário Mulheres do Brasil. p. 43. 
Como visto, a Constituição Brasileira de 1891 não proibia expressamente o voto feminino. Com efeito, o artigo 70 da carta constitucional estabelecia o seguinte:

Art 70 - São eleitores os cidadãos maiores de 21 anos que se alistarem na forma da lei. $\S 1^{\circ}$ - Não podem alistar-se eleitores para as eleições federais ou para as dos Estados:

$1^{\circ}$ ) os mendigos;

$2^{\circ}$ ) os analfabetos;

$3^{\circ}$ ) as praças de pré, excetuados os alunos das escolas militares de ensino superior;

$4^{\circ}$ ) os religiosos de ordens monásticas, companhias, congregações ou comunidades de qualquer denominação, sujeitas a voto de obediência, regra ou estatuto que importe a renúncia da liberdade Individual. ${ }^{169}$

Porém, considerando que, durante a Assembleia Constituinte, foi proposta uma série de emendas que estabeleciam explicitamente o direito de voto às mulheres, sendo todas as emendas recusadas, muitos defenderam que as mulheres continuavam excluídas do eleitorado.

Por outro lado, havia quem defendesse que, sendo as mulheres cidadãs brasileiras e não estando expressamente excluídas na forma do parágrafo $1^{\circ}$ do art. 70 da Constituição, teriam elas o direito de votar. Clovis Bevilaqua, jurista brasileiro, encontrava-se entre esse segundo grupo:

Para Bevilacqua, a mulher era cidadão brasileira (art. 69), não perderia sua qualidade de brasileira pelo casamento, antes influindo para tornar seu cônjuge brasileiro, se se casasse com estrangeiro. Queria isto dizer que, no sistema constitucional que nos regia, a cidadania era qualidade que a lei assegurava à mulher de modo mais completo. Consequentemente, os deveres e direitos do brasileiro lhe competiam como ao homem. Assim, quando a Constituição declarava, no art. 70, eleitores os cidadãos maiores de 21 anos, que se alistassem na forma da lei, abrangia o homem e a mulher, porque ambos eram cidadãos e porque, como é sabido, onde a lei não distingue, não deve o intérprete distinguir. $^{170}$

Em 1917, Maurício de Lacerda apresentou proposta de emenda à lei eleitoral consagrando o direito ao voto para a mulher brasileira, sendo o primeiro projeto desde a Constituinte de 1891 que pretendia conferir direitos

\footnotetext{
${ }^{169}$ Constituição da República dos Estados Unidos do Brasil de 24 de fevereiro de 1891. Disponível em $<$ http://www.planalto.gov.br/ccivil_03/constituicao/constituica091.htm $>$. Acesso em 8 de outubro de 2017.

${ }^{170}$ PORTO, Walter Costa. O voto no Brasil. pp. 234 e 235.
} 
políticos à mulher de que se tem notícia. Porém, o projeto foi considerado inconstitucional e rejeitado. ${ }^{171}$

Em 1919, o senador Justo Chermont apresentou projeto de lei que dispunha sobre a capacidade eleitoral da mulher maior de 21 anos. Para Chermont, o Brasil deveria seguir o exemplo de outros países que tivessem conferido igualdade de direitos às mulheres, apesar de também sustentar que a maternidade seria a principal função da mulher no mundo. ${ }^{172} \mathrm{Em} \mathrm{1921 \text {,o }}$ Senado aprovou o projeto de lei apresentado por Chermont. Leolinda Daltro compareceu ao Congresso, juntamente com um grupo de mulheres convocadas pelo Partido Republicano Feminino, para assistir à votação, dando início à estratégia de pressão política amplamente empregada pelo movimento sufragista brasileiro. ${ }^{173}$ Entretanto, o referido projeto de lei não chegou a ser convertido em lei.

O projeto de Nogueira Penido e Bittencourt Filho, apresentado em 1921, também não obteve sucesso. As lideranças da Federação Brasileira pelo Progresso Feminino promoveram forte campanha à época, assistindo às sessões do Congresso. Apresentaram petição assinada por duas mil mulheres exigindo a aprovação da lei, mas ainda assim o projeto não foi aprovado. ${ }^{174}$

De qualquer forma, a apresentação desses projetos conferia maior legitimidade ao pleito pelo sufrágio feminino e ajudou a construir um símbolo para a organização do movimento sufragista. ${ }^{175}$

Em 1927, o candidato ao governo do Rio Grande do Norte Juvenal Lamartine de Faria incluiu em sua plataforma a promessa de direitos políticos plenos às mulheres. Expressou "o desejo de contar com o concurso da mulher

\footnotetext{
${ }^{171}$ KARAWEJCZYK, Mônica. Os primórdios do movimento sufragista no Brasil. p. 78.

${ }^{172}$ HAHNER, June E. A mulher brasileira e suas lutas sociais e politicas. p. 113.

${ }^{173}$ KARAWEJCZYK, Mônica. Os primórdios do movimento sufragista no Brasil. pp. 80 e 81.

${ }^{174}$ HAHNER, June E. A mulher brasileira e suas lutas sociais e politicas. p. 113.

${ }^{175}$ HAHNER, June E. A mulher brasileira e suas lutas sociais e politicas. p. 113.
} 
"não só na escolha daqueles que veem representar o povo" como também "entre os que elaboram e votam a lei que tiver de aplicar"". ${ }^{176}$ Defendia, portanto, o direito das mulheres de votar e ser votadas.

No mesmo ano, foi elaborada a lei eleitoral do estado do Rio Grande do Norte, e Juvenal Lamartine solicitou a José Augusto Bezerra, então governador do estado, que incluísse emenda conferindo direito de voto às mulheres. Com isso, foi incluído o seguinte texto nas Disposições Transitórias da lei:

Art. 17 - No Rio Grande do Norte, poderão votar e ser votados, sem distinção de sexos, todos os cidadãos que reunirem as condições exigidas por esta lei. ${ }^{177}$

Desse modo, o Rio Grande do Norte foi o primeiro Estado brasileiro a aprovar o sufrágio feminino. Com base nesse dispositivo, a professora Celina Guimarães Viana alistou-se como eleitora, obtendo decisão judicial que determinava sua inclusão na lista geral dos eleitores. ${ }^{178} \mathrm{O}$ livro "Os Direitos Políticos da Mulher (Despachos)", editado em Natal em 1928, reúne decisões judiciais de três processos da Justiça do Rio Grande do Norte, que deferiram o pedido de inclusão no alistamento eleitoral de determinados municípios do referido estado a Julia Alves Barbosa, Maria de Lourdes Lamartine e Marta de Medeiros, todas professoras.

Examinando a questão da possibilidade ou não do voto feminino, os três juízes se manifestaram pela capacidade eleitoral das mulheres. M. Xavier C. Montenegro, juiz de direito de Natal, pôs-se a examinar a constitucionalidade do sufrágio feminino. Afirma que os constitucionalistas J. Barbalho, Aristides Milton e Carlos Maximiliano rejeitavam o direito de voto de mulheres considerando terem sido rechaçadas todas as emendas apresentadas na constituinte brasileira nesse sentido. Por outro lado, o constitucionalista Araujo Castro defendia que o voto feminino estava implicitamente contido nas

\footnotetext{
${ }^{176}$ PORTO, Walter Costa. O voto no Brasil. pp. 235 e 236.

${ }^{177}$ PORTO, Walter Costa. O voto no Brasil. p. 236.

${ }^{178}$ PORTO, Walter Costa. O voto no Brasil. p. 236.
} 
cláusulas constitucionais. Isso porque o artigo 69 da Constituição reconhecia a mulher como cidadã brasileira, e o artigo 70 considerava eleitores os cidadãos acima de 21 anos. Além disso, o parágrafo $1^{\circ}$ do artigo 70 nega capacidade eleitoral somente aos mendigos, analfabetos, praças de pré (militar de categoria hierárquica inferior) e religiosos sujeitos a voto de obediência. "Ora, ninguém, de boa fé, poderá incluir as mulheres em qualquer das supracitadas exceções", escreveu o juiz em sua sentença. ${ }^{179}$

Para o juiz, não haveria nenhuma incongruência maior do que negar o direito de voto às mulheres, enquanto lhes eram concedidos outros direitos, também políticos, de maior relevância, como o acesso a funções públicas. Considerando que as mulheres são cidadãs brasileiras, e que exercem muitos outros direitos políticos, o juiz entendeu que o direito de inscrição eleitoral das mulheres estava rigidamente amparado no texto constitucional. Assim, desde que não se enquadrassem nas proibições expressas ao direito ao voto, deveriam ser admitidas às funções eleitorais.

A respeito do argumento de que as mulheres não estariam inseridas no conceito de "cidadãos", o juiz escreveu:

Argumenta-se que, no vocábulo - cidadãos - não se pode conter a expressão verbal as mulheres. Mas aceitar uma tal argumentação importaria chegar à seguinte absurda conclusão: não sendo as mulheres consideradas cidadãos, restariam estrangeiras, isto é, deixariam de ser nacionais. Entretanto, os estrangeiros no Brasil, uma vez naturalizados, gozam do direito de voto. Seria assim o caso de naturalizar a mulher brasileira a fim de que pudesse ela vir a gozar de direitos conferidos a estrangeiros naturalizados. ${ }^{180}$

Concluiu M. Xavier Montenegro que o direito das mulheres brasileiras ao sufrágio eleitoral era irrecusável, em face do texto constitucional e das leis federais em vigor, determinando que o nome da srta. Julia Alves Barbosa fosse incluído no registro cívico de Natal, em 1927.

\footnotetext{
${ }^{179}$ Os Direitos Políticos da Mulher (Despachos). Natal: Edição da Imprensa Oficial, 1928. Disponível em $<$ http://www.stf.jus.br/bibliotecadigital/DominioPublico/45051/pdf/45051.pdf $>$. Acesso em $8 \mathrm{de}$ outubro de 2017. p. 9.

${ }^{180}$ Os Direitos Políticos da Mulher (Despachos). p. 12.
} 
O juiz Silverio Soares de Souza também admitiu ser forçoso reconhecer o direito da mulher ao voto, apesar de pessoalmente ser inteiramente contrário ao sufrágio feminino. Relembrou $\mathrm{o}$ argumento de que todas as emendas apresentadas na constituinte de 1891 que conferiam tal direito às mulheres foram rejeitadas, e que, portanto, deveria ser respeitada a vontade dos constituintes. Afirmou que por algum tempo esse fator o havia convencido de que as mulheres estavam privadas de exercer a função eleitoral. No entanto, posteriormente chegou à conclusão de que esse argumento não procede, visto que não seria possível determinar, ao certo, qual o fundamento para rejeição das emendas:

(...) em face das discussões que, na Constituinte, se travaram, em torno das sobreditas emendas, não se sabe, ao certo, se a maioria as rejeitou sob o fundamento, em que se estribou Pedro Americo, de se não dever "arrastar para o turbilhão das paixões políticas a parte serena e angélica do gênero humano", ou se o foi, sob o fundamento, em que se esteou Almeida Nogueira, de ser "escusada e inconveniente a menção especial e expressa (a que as duas emendas faziam) visto achar-se compreendido, implicitamente, o direito das mulheres ao alistamento eleitoral e ao exercício do voto na generalidade dos termos do projeto constitucional e de todas as leis e regulamentos eleitorais. $^{181}$

Dessa forma, entendeu o juiz não ser possível determinar que estava na intenção dos constituintes afastar a mulher do direito de voto. Sendo a interpretação histórica dúbia, o intérprete deveria se ater ao texto legal. Sendo assim, determinou a inclusão da srta. Maria de Lourdes Lamartine no alistamento eleitoral de Natal, em sentença de 1928.

No terceiro processo incluído no livro, o juiz da comarca de Acary João Francisco Dantas Salles determinou, em 1927, o alistamento eleitoral de D. Martha Maria de Medeiros no município. Fundou-se no argumento de que as mulheres são cidadãos brasileiros ("se não o fossem, seriam estrangeiros, mas pertencentes a que país?”) ${ }^{182}$, e que, desde que não se incluam em nenhuma exceção expressa prevista na Constituição, não se poderia deixar de

\footnotetext{
${ }^{181}$ Os Direitos Políticos da Mulher (Despachos). p. 20.

${ }^{182}$ Os Direitos Politicos da Mulher (Despachos). p. 25.
} 
reconhecer-lhes o direito de se alistarem como eleitoras.

Até 1928, vinte mulheres se inscreveram como eleitoras no Rio Grande do Norte. Nas eleições senatoriais de 1928, quinze dessas mulheres votaram. ${ }^{183}$ No entanto, a Comissão de Poderes do Senado determinou que esses votos seriam "inapuráveis", descontando-os do total obtido pelo único candidato. No Parecer $n^{0}$ 8/1928, a Comissão entendeu que, embora a Constituição não vedasse os direitos políticos à mulher, também não os outorgava, e a falta de proibição não poderia ser suficiente para conferir tais direitos. Além disso, entendeu que existia uma longa tradição, costumeira e doutrinária, de negativa do voto à mulher, que deveria ser considerada. ${ }^{184}$

A Comissão concluiu ser necessária a edição de uma lei que interpretasse o texto constitucional e definisse a matéria:

Ainda quando o verdadeiro pensamento da Constituição tenha sido até agora erradamente interpretado; que a interpretação vigente esteja mantendo a título precário, ou que ao mesmo texto se deva insuflar um espírito novo, a que se não opõe a sua letra, faz-se mister uma manifestação inequívoca dos poderes políticos do país, a qual, traduzindo o sentir e o pensar dominante na coletividade, por um largo movimento da opinião nacional, se exteriorize ou numa lei do Congresso (com a colaboração do Executivo, pela sanção), ou num decreto do Poder Judiciário, pelos seus órgãos competentes, para ser restaurado o pensamento exato do legislador constituinte. ${ }^{185}$

A Federação Brasileira pelo Progresso Feminino, em resposta à decisão da Comissão de Poderes do Senado de anular os votos de mulheres na eleição senatorial, lançou um manifesto na forma de uma "Declaração dos Direitos da Mulher". Tal manifesto foi assinado por nomes influentes, como Bertha Lutz, Gerônima Mesquita, Maria Eugênia Celso e Clotilde de Mello Vianna (mulher do vice-presidente do Brasil). Associavam o voto feminino à base dos direitos humanos: "As mulheres, assim como os homens, nascem membros livres e independentes da espécie humana, dotados de faculdades equivalentes e igualmente chamados a exercerem, sem peias, os seus direitos e deveres

\footnotetext{
${ }^{183}$ PORTO, Walter Costa. O voto no Brasil. p. 237.

${ }^{184}$ PORTO, Walter Costa. O voto no Brasil. pp. 237 e 238.

${ }^{185}$ PORTO, Walter Costa. O voto no Brasil. p. 238.
} 
individuais". ${ }^{186}$ Além disso, argumentavam que aqueles que pagam impostos e obedecem às leis devem ter o direito de intervir em sua elaboração; do contrário, trata-se de uma tirania "incompatível com os governos baseados na Justiça" 187 . Por fim, afirmavam que o voto era "o único meio legítimo de defender" os direitos à vida e à liberdade. ${ }^{188}$

Segundo Hahner, o manifesto deixou evidente que os direitos políticos não eram privilégios, mas sim direitos inalienáveis que deveriam ser assegurados à mulher brasileira, sob pena de cometer-se grave injustiça. ${ }^{189}$

\subsection{CÓDIGO ELEITORAL DE 1932}

Em 1930, Getúlio Vargas subiu ao poder e o regime provisório anunciou a decisão de criar um novo código eleitoral. O anteprojeto do código, liberado em 1931 pelo governo, contemplava o voto feminino, mas de forma limitada:

art. $7^{\circ}$ - É eleitor todo cidadão de 21 anos, ou que tenha, por disposição da Lei civil, adquirido já a maioridade e que, não incorrendo em nenhuma das proibições do art. 11, se achar alistado no Registro Cívico.

art. $8^{\circ}$ - São admitidos a inscrever-se eleitoras, desde que preencham as demais condições legais:

a) mulher solteira sui juris, que tenha economia própria e viva de seu trabalho honesto ou do que lhe rendam bens, empregos ou qualquer outra fonte de renda lícita;

b) viúva em iguais condições;

c) a mulher casada, que exerça efetivamente o comércio ou indústria por conta própria ou como chefe, gerente, empregada, ou simples operária de estabelecimento comercial ou industrial, e bem assim que exerça efetivamente qualquer lícita profissão, com escritório, consultório ou estabelecimento próprio ou em que tenha funções, devidamente autorizada pelo marido, na forma da lei civil.

art. $9^{\circ}$ - Ainda são alistáveis, nas condições do art. antecedente:

a) a mulher separada por desquite amigável ou judicial, enquanto durar a separação; b) aquela que, em consequência da declaração judicial da ausência do marido, estiver à

\footnotetext{
${ }^{186}$ HAHNER, June E. A mulher brasileira e suas lutas sociais e politicas. pp. 117 e 118.

${ }^{187}$ ALVES, Branca Moreira. Ideologia e feminismo. p. 121.

188 ALVES, Branca Moreira. Ideologia e feminismo. p. 121.

${ }^{189}$ HAHNER, June E. A mulher brasileira e suas lutas sociais e politicas. p. 118.
} 
testa dos bens do casal, ou na direção da família; c) aquela que foi deixada pelo marido durante mais de dois anos, embora esteja este em lugar sabido. ${ }^{190}$

A Federação Brasileira pelo Progresso Feminino, juntamente com outros grupos como a Aliança Cívica das Brasileiras e a Aliança Nacional de Mulheres, insatisfeitas com as disposições do anteprojeto, lançaram uma campanha para que fossem excluídas as limitações ao voto feminino.

Assim, o Código Eleitoral, aprovado pelo Decreto $\mathrm{n}^{0} 21.076$ de 1932, eliminou a previsão do voto qualificado, trazendo a seguinte redação:

Art. $2^{\circ}$ - É eleitor o cidadão maior de 21 anos, sem distinção de sexo, alistado na forma deste Código. ${ }^{191}$

\subsection{CONSTITUINTE E CONSTITUIÇÃO DE 1934}

Após a vitória de 1932, era necessário assegurar que a nova constituição também iria garantir a igualdade de direitos políticos às mulheres. Uma forma de seguramente intervir no texto constitucional seria participar de sua criação. Assim, Bertha Lutz, apoiada pela Federação Brasileira pelo Progresso Feminino, e Nathercia Silveira, líder da Aliança Nacional de Mulheres, participaram da comissão organizadora do anteprojeto constitucional. ${ }^{192}$

Nas eleições para a Constituinte, ocorridas em 1933, Bertha Lutz (Rio de Janeiro) e Carlota Pereira de Queiroz (São Paulo) concorreram. Carlota de Queiroz foi eleita, sendo a primeira deputada federal do Brasil e única representante do sexo feminino na constituinte de 1933/34.

As discussões travadas na Assembleia Constituinte foram acompanhadas

\footnotetext{
${ }^{190}$ PORTO, Walter Costa. O voto no Brasil. pp. 238 e 239.

191 BRASIL. Decreto $\mathrm{n}^{\mathrm{o}} 21.076$ de 24 de fevereiro de 1932. Disponível em $<$ http://www2.camara.leg.br/legin/fed/decret/1930-1939/decreto-21076-24-fevereiro-1932-507583publicacaooriginal-1-pe.html>. Acesso em 6 de novembro de 2017.

${ }^{192}$ ALVES, Branca Moreira. Ideologia e feminismo. p. 126.
} 
de perto pelas lideranças sufragistas, de modo a evitar eventuais retrocessos ou prejuízos às conquistas obtidas. Rachel Soihet menciona uma emenda que estabeleceria, como condição para o exercício do voto, a prestação de serviço militar feminino, que curiosamente foi assinada por Carlota de Queiroz. A proposta foi fortemente criticada pelas feministas da época - as quais, inclusive, vaiaram os deputados que apoiavam a emenda, em manifestação mais enfática do que a postura comedida que havia caracterizado o movimento. A emenda acabou por ser rejeitada. ${ }^{193}$

A Constituição de 1934, confirmando a vitória de 1932, estabeleceu que "são eleitores os brasileiros de um e de outro sexo, maiores de 18 anos, que se alistarem na forma da lei”. ${ }^{194}$

Entretanto, a Constituição não igualou o voto feminino ao masculino: determinou que o voto seria obrigatório para os homens e facultativo para as mulheres, salvo para aquelas que exercessem função pública remunerada. ${ }^{195}$ Apenas essas eram obrigadas a votar, enquanto para todos os homens o voto era obrigatório. Somente o Código Eleitoral de 1965 veio a estabelecer a igualdade entre o voto feminino ao masculino, tornando todos obrigatórios. ${ }^{196}$

O que se verificou após a consolidação da vitória na Constituição de 1934 foi um esvaziamento do movimento. Apesar dos esforços das lideranças da FBPF, que publicaram no Jornal do Brasil manifesto chamando as mulheres a votarem para eleger candidatos que as representassem, relativamente poucas mulheres se alistaram para votar.

${ }^{193}$ SOIHET, Rachel. A pedagogia da conquista do espaço público pelas mulheres e a militância feminista de Bertha Lutz. p. 105.

${ }^{194}$ Constituição da República dos Estados Unidos do Brasil de 16 de julho de 1934. Disponível em $<$ http://www.planalto.gov.br/ccivil_03/constituicao/constituicao34.htm $>$. Acesso em 12 de outubro de 2017.

${ }^{195}$ Artigo 109 da Constituição da República dos Estados Unidos do Brasil de 16 de julho de 1934.

196 Série Inclusão: a conquista do voto feminino no Brasil. Disponível em $<$ http://www.tse.jus.br/imprensa/noticias-tse/2013/Abril/serie-inclusao-a-conquista-do-voto-femininono-brasil $>$. Acesso em 30 de outubro de 2017. 
Após conquistado o direito de voto, principal símbolo do movimento, a luta pelos direitos da mulher foi perdendo força. Como colocou Branca Moreira Alves, a luta perdeu o ritmo de urgência anterior, que animara as militantes a prosseguirem frente aos obstáculos. O voto, que seria um instrumento para a obtenção de outros direitos, “depois de anos de organização concentrada unicamente em sua obtenção, deixou de ser um meio e passou a confundir-se com o próprio fim". 197

\subsection{ALGUMAS CONSIDERAÇÕES SOBRE O MOVIMENTO SUFRAGISTA BRASILEIRO}

À guisa de conclusão, cabem alguns comentários e críticas acerca do processo de conquista do sufrágio feminino no Brasil. Em primeiro lugar, não se pode deixar de apontar que essa conquista foi fruto das lutas e mobilizações das próprias mulheres brasileiras, que tomaram consciência de sua sujeição política, muitas vezes inspiradas nas lutas de sufragistas de outros países. Assim, o direito ao voto feminino não foi uma concessão dos homens, ainda que a participação masculina tenha sido importante, e até mesmo necessária, no processo (e não poderia ser diferente, pois, considerando que os homens detinham o poder político, a extensão do sufrágio às mulheres dependia em alguma medida do apoio deles).

Por outro lado, também há de ser notado o caráter elitista do movimento. Ainda que o sufragismo brasileiro tenha contado com a participação de mulheres trabalhadoras e de classes mais baixas, a maior parte das participantes e as principais líderes do movimento pertenciam às classes média e alta. De um lado, isso pode ser explicado pelo fato de que essas mulheres

${ }^{197}$ ALVES, Branca Moreira. Ideologia e feminismo. p. 127. 
tiveram acesso a leituras, muitas vezes estudando em países como Inglaterra e Estados Unidos e entrando em contato com movimentos sufragistas de outras regiões, além de que muitas das líderes brasileiras pertenciam a famílias da burguesia, que tinham contato pessoal com parlamentares e políticos influentes. Os contatos estabelecidos com homens de poder inegavelmente facilitaram a conquista do sufrágio. Porém, isso não significa, em momento algum, que outras mulheres brasileiras, de diferentes classes sociais, não estivessem lutando pelos seus direitos ou por outras causas. Antonieta de Barros e Almerinda Gama, como visto, são exemplos de sufragistas negras que tinham nítido viés social, seja através da educação, seja na luta sindical.

Outra crítica que pode ser feita ao movimento brasileiro é que as líderes sufragistas não buscavam uma ruptura radical com o status quo, não questionavam a posição de sujeição da mulher na sociedade. Rachel Soihet escreveu que historiadoras como Susan K. Besse e June Hahner consideram que "numa sociedade autoritária, patriarcal e capitalista" as sufragistas “contribuíram, no máximo, para a modernização das relações de gênero". ${ }^{198}$ Como visto, para justificar a defesa do voto feminino, as sufragistas enfatizavam a posição das mulheres como mães e colaboradoras dos homens. Não questionavam as raízes da sujeição da mulher, as relações de poder familiar, nem faziam uma crítica social profunda.

No entanto, é preciso ponderar que as sufragistas tentaram adaptar sua luta ao contexto social em que estavam inseridas. Foram apresentados, neste trabalho, alguns dos argumentos utilizados pelos anti-sufragistas, a partir dos quais é possível ver que a ideia de que o voto feminino acarretaria a dissolução da família brasileira era amplamente difundida. Uma atitude radical de confronto com os grupos de poder da época poderia levar a um fracasso total

\footnotetext{
${ }^{198}$ SOIHET, Rachel. A pedagogia da conquista do espaço público pelas mulheres e a militância feminista de Bertha Lutz. p. 105.
} 
do movimento, pensavam as sufragistas. $\mathrm{O}$ receio de que um ataque ao sistema e aos valores da sociedade pusesse a perder a luta pelo sufrágio fez com que as lideranças do movimento adotassem um tom moderado para o seu discurso, buscando convencer os homens de que o papel de mãe e esposa da mulher não seria afetado.

Por fim, uma importante crítica feita por algumas pesquisadoras do tema, como Gisela Bester, é que a conquista de direitos políticos pelas mulheres na década de 1930 não significou, na verdade, uma emancipação política plena das mulheres brasileiras. Isso porque grande parte das brasileiras continuaram excluídas - as analfabetas. ${ }^{199}$ A vedação do direito ao voto aos analfabetos foi implementada no Brasil em 1881, com a chamada Lei Saraiva (Decreto ${ }^{\circ}$ 3.029 de 9 de janeiro de 1881), que estabeleceu o "censo literário" ${ }^{200}$, isto é, a exigência de que o eleitor soubesse ler e escrever corretamente. $\mathrm{O}$ voto somente foi estendido aos analfabetos, em caráter facultativo, em 1985, com a promulgação da Emenda Constitucional $\mathrm{n}^{\circ}$ 25. A Constituição de 1988 confirmou esse direito, ainda de forma facultativa. Contudo, a extensão se deu no âmbito ativo dos direitos políticos (direito de votar), mas não no âmbito passivo (direito de ser votado). Os analfabetos, ainda na Constituição de 1988, são inelegíveis.

Bester fez um levantamento detalhado de dados do Instituto Brasileiro de Geografia e Estatística (IBGE) relativos a índices de analfabetismo por grupos de gênero e idade no Brasil (censos de 1970 e 1991), de modo a evidenciar que as taxas de analfabetismo foram historicamente maiores entre mulheres do que homens. Saliente-se que, dentre as analfabetas, a superioridade numérica era de mulheres negras. Assim, ainda que o direito ao voto feminino tenha sido

\footnotetext{
${ }^{199}$ BESTER, Gisela Maria. A Luta sufrágica feminina e a conquista do voto pelas mulheres brasileiras. p. 338.

${ }^{200}$ Série Inclusão: a luta dos analfabetos para garantir seu direito ao voto na República. Disponível em $<$ http://www.tse.jus.br/imprensa/noticias-tse/2013/Abril/serie-inclusao-a-luta-dos-analfabetos-paragarantir-seu-direito-ao-voto-na-republica>. Acesso em 27 de outubro de 2017.
} 
conquistado em 1932, até 1985 grande parte das mulheres continuaram excluídas da participação política, via analfabetismo. ${ }^{201}$

As organizações sufragistas brasileiras, talvez por serem compostas por mulheres de classes média e alta, não tinham dentre seus pleitos a alfabetização de mulheres e nem a extensão de direitos políticos aos analfabetos, o que permite concluir, portanto, que a conquista do voto feminino não significou uma participação política plena da mulher brasileira. Ainda assim, foi, certamente, uma importante conquista feminina na luta pela igualdade política.

${ }^{201}$ BESTER, Gisela Maria. Direitos politicos das mulheres brasileiras. pp. 114 a 122. 


\section{CONCLUSÃO}

A conquista do sufrágio feminino representou, no Brasil e em outras democracias do mundo, um passo fundamental na luta de mulheres por direitos políticos e igualdade de gênero. Significou uma reivindicação de participação das mulheres no processo de tomada de decisão pública, espaço tradicionalmente masculino.

Em uma democracia, a titularidade de todo poder é do povo, sendo a soberania popular princípio fundamental de todo e qualquer regime democrático. Porém, o povo outorga as funções de governo a representantes, na medida em que seria inviável que todos os indivíduos de uma sociedade exercessem as funções de Estado diretamente. Considerando que a fonte primária do poder é do povo, o exercício desse poder pelos governantes só é legitimado pelo voto, por meio do qual o povo expressa a sua vontade.

As mulheres, como todos os cidadãos, são afetadas pelas decisões tomadas pelos representantes do povo, porém, por muito tempo, não tinham voz no processo de escolha de tais representantes. Havia, portanto, um grande desequilíbrio entre os direitos de homens e mulheres; todos eram submetidos às decisões dos governantes, mas apenas os homens tinham o direito de eleger aqueles que tomariam as decisões.

Assim, a luta pelo direito ao sufrágio se originou da conscientização das mulheres de sua situação de exclusão da vida política e de sujeição em relação aos homens. As sufragistas demandavam lugar no espaço público e no processo decisório democrático, como forma de conquistarem outros direitos, o que só seria possível a partir do momento em que fossem ouvidas pelos governantes.

Essa conscientização não foi verificada apenas no Brasil. O capítulo dois, 
que descreveu em linhas gerais a luta sufrágica em outros países ocidentais, demonstrou que a ideia do voto como um instrumento para a conquista de outros direitos e, em última análise, para a superação de desigualdades entre homens e mulheres esteve presente nos movimentos sufragistas de todos esses países.

Entretanto, assim como ocorreu em outros lugares, o movimento sufragista brasileiro, a partir do século XX, adquiriu tom moderado, buscando se adaptar aos padrões tradicionais da sociedade, que impunham o papel da mulher voltado para a família, para a vida doméstica. Podemos dizer que as sufragistas não buscavam romper com o contrato sexual (utilizando o termo criado por Carole Pateman, conforme discutido no primeiro capítulo deste trabalho). Pelo contrário, utilizavam o papel da mulher como mãe em sua argumentação, afirmando que uma maior participação na vida pública faria com que as mulheres desempenhassem melhor suas atividades domésticas e a sua função de educar os filhos.

A principal crítica ao movimento pelo sufrágio feminino no Brasil reside no fato de que grande parte das brasileiras continuaram excluídas do processo eleitoral mesmo após a conquista de 1932. Ainda que as líderes sufragistas brasileiras tenham rejeitado fortemente o voto qualificado, isto é, o voto feminino condicionado a questões como profissão ou estado civil da mulher, o que foi proposto diversas vezes por homens defensores do sufrágio (e, inclusive, esteve presente no anteprojeto de Código Eleitoral do governo Vargas), elas não demandaram o voto para analfabetos.

Até 1985, analfabetos continuaram excluídos da categoria de eleitores e, conforme apontado no terceiro capítulo deste estudo, a pesquisadora Gisela Bester demonstrou, a partir de dados do Instituto Brasileiro de Geografia e Estatística (IBGE), que a superioridade numérica de analfabetos foi, historicamente, de mulheres negras. Sendo assim, mesmo após 1932, grande 
parte das mulheres brasileiras continuaram sem ter os direitos políticos assegurados: as analfabetas.

Portanto, embora a conquista do sufrágio feminino tenha ocorrido em 1932, sendo confirmada pela Constituição de 1934, isso não significou uma emancipação política plena das mulheres brasileiras, visto que muitas delas permaneceram excluídas da vida política até a década de 1980. Vale notar, ainda, que os analfabetos possuem, até hoje, apenas metade dos direitos políticos garantidos, na medida em que, já sob a égide da Constituição de 1988, continuam não sendo elegíveis.

Não obstante todas as críticas que podem ser feitas ao movimento, a conquista do sufrágio feminino foi essencial na luta por igualdade de direitos entre homens e mulheres, sendo um relevante tema de estudo que, inclusive, nos permite realizar reflexões sobre a sociedade patriarcal em que vivemos, reflexões essas que continuam atuais décadas depois dos eventos narrados neste trabalho. 


\section{BIBLIOGRAFIA}

$19^{\text {th }}$ Amendment to the U.S. Constitution: Women's Right to Vote. Disponível em <https://www.archives.gov/historical-docs/19th-amendment>. Acesso em 15 de outubro de 2017.

ABREU, Zina. Luta das mulheres pelo direito de voto: movimentos sufragistas na Grã-Bretanha e nos Estados Unidos. ARQUIPÉLAGO-Revista da Universidade dos Açores, p. 443-469, 2002.

ALVES, Branca Moreira. Ideologia e feminismo: a luta da mulher pelo voto no Brasil. Petrópolis: Vozes, 1980. 200p.

BARRANCOS, Dora. Los caminos del feminismo en la Argentina: historia y derivas. Voces en el Fénix, v. 32, p. 6-13, 2014.

BESTER, Gisela Maria. A Luta sufrágica feminina e a conquista do voto pelas mulheres brasileiras: aspectos históricos de uma caminhada. Argumenta Journal Law, n. 25, p. 327-344, 2017.

BESTER, Gisela Maria. Direitos políticos das mulheres brasileiras: aspectos históricos da luta sufrágica e algumas conquistas políticas posteriores. Florianópolis. 1996. 194 p. Dissertação (Mestrado em Ciências Humanas Especialidade Direito) - Centro de Ciências Jurídicas da Universidade Federal de Santa Catarina.

BOBBIO, Norberto. Teoria Geral da Política: a filosofia política e as lições dos clássicos. São Paulo: Elsevier, 2000. 720p.

BOBBIO Norberto; MATTEUCCI Nicola; PASQUINO Gianfranco. Dicionário de política. Trad. de Carmen C, Varriale et. al.; coord. trad. João Ferreira; rev. geral João Ferreira e Luis Guerreiro Pinto Cacais. $11^{\mathrm{a}}$ ed. Brasília: Editora Universidade de Brasília, 1998. 1.330p.

BRASIL. Constituição da República Federativa do Brasil de 1988. Disponível em

http://www.planalto.gov.br/ccivil_03/constituicao/constituicaocompilado.htm> . Acesso em 3 de novembro de 2017.

. Constituição da República dos Estados Unidos do Brasil de 24 de fevereiro de 1891 . Disponível em $<$ http://www.planalto.gov.br/ccivil_03/constituicao/constituicao91.htm>. Acesso em 8 de outubro de 2017.

de . Constituição da República dos Estados Unidos do Brasil de 16 julho de $1934 . \quad$ Disponível em 
$<$ http://www.planalto.gov.br/ccivil_03/constituicao/constituicao34.htm>. Acesso em 12 de outubro de 2017.

. Decreto $\mathrm{n}^{\circ} 21.076$ de 24 de fevereiro de 1932. Disponível em $<$ http://www2.camara.leg.br/legin/fed/decret/1930-1939/decreto-21076-24fevereiro-1932-507583-publicacaooriginal-1-pe.html>. Acesso em 6 de novembro de 2017.

BRAZIL, Érico Vital e SCHUMAHER, Schuma (org.). Dicionário Mulheres do Brasil: de 1500 até a atualidade. $2^{\text {a }}$ edição. Rio de Janeiro: Jorge Zahar. 676p.

CANÊDO, Letícia Bicalho (org.). Sufrágio universal e a invenção democrática. São Paulo: Estação Liberdade, 2005. 512p.

COMPARATO, Fábio Konder. A afirmação histórica dos Direitos Humanos. 6 ed. São Paulo: Saraiva, 2008. 577p.

DOMINGUES, Petrônio. Frentenegrinas: notas de um capítulo da participação feminina na história da luta anti-racista no Brasil. cadernos pagu, n. 28, p. 345-374, 2007.

FALCARI, Gisele. Antonieta de Barros: protagonista de uma história. Disponível em < https://www.geledes.org.br/antonieta-de-barros-protagonistade-uma-mudanca/>. Acesso em 5 de novembro de 2017.

FERREIRA FILHO, Manoel Gonçalves. Curso de Direito Constitucional. 22a ed. atual. São Paulo: Saraiva, 1995. 322p.

FINLEY, M.I. Democracia antiga e moderna. Rio de Janeiro: Graal, 1988. $192 \mathrm{p}$.

HAHNER, June E. A mulher brasileira e suas lutas sociais e políticas: 1850-1937. Tradução de Maria Thereza P. de Almeida e Heitor Ferreira da Costa. São Paulo: editora Brasiliense, 1981. 140p.

KARAWEJCZYK, Mônica. Os primórdios do movimento sufragista no Brasil: o feminismo "pátrio" de Leolinda Figueiredo Daltro. Estudos IberoAmericanos, v. 40, n. 1, 2014.

MARTÍNEZ, Laura Pellicer. El sufragio femenino en América Latina. Disponível em $<$ http://www.antrophistoria.com/2016/02/el-sufragio-femeninoen-america-latina.html $>$. Acesso em 14 de outubro de 2017.

MIGUEL, Luis Felipe. Carole Pateman e a crítica feminista do contrato. Revista Brasileira de Ciências Sociais, v. 32, n. 93, 2017. Disponível em < http://www.scielo.br/pdf/rbcsoc/v32n93/0102-6909-rbcsoc-3293032017.pdf>. Acesso em 27 de outubro de 2017. 
MILLS, Charles W. O Contrato de dominação. Meritum, revista de Direito da Universidade FUMEC, v. 8, n. 2, 2013.

NAZARIO, Diva Nolf. Voto feminino e feminismo. São Paulo: Imprensa Oficial do Estado de São Paulo, 2009. 232p.

OLIVEIRA, Adriana Vidal de. A Constituição da Mulher Brasileira: uma análise dos estereótipos de gênero na Assembleia Constituinte de 19871988 e suas consequências no texto constitucional. Rio de Janeiro. 2012. 465 p. Tese (Doutorado em Direito) - Departamento de Direito da PUC-Rio.

Os Direitos Políticos da Mulher (Despachos). Natal: Edição da Imprensa

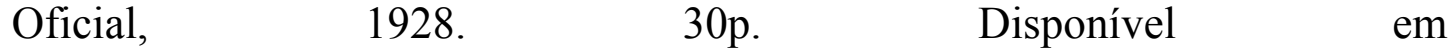
$<$ http://www.stf.jus.br/bibliotecadigital/DominioPublico/45051/pdf/45051.pdf >. Acesso em 8 de outubro de 2017.

OSTA VÁZQUEZ, María Laura. Discussões feministas no século XIX. Revista NUPEM, v. 6, n. 11, p. 23-38, 2014. Disponível em < http://www.fecilcam.br/revista/index.php/nupem/article/viewFile/547/324>. Acesso em 27 de outubro de 2017.

PARDO, Adolfo. Historia de la mujer en Chile: La conquista de sus derechos políticos en el siglo XX (1900-1952). Disponível em $<\mathrm{http}$ //critica.cl/historia/historia-de-la-mujer-en-chile-la-conquista-losderechos-politicos-en-el-siglo-xx-1900-1952>. Acesso em 15 de outubro de 2017.

PATEMAN, Carole. O Contrato Sexual. Tradução de Marta Avancini. Rio de Janeiro: Paz e Terra, 1993. 345p.

PORTO, Walter Costa. $O$ voto no Brasil: da Colônia à $6^{\mathrm{a}}$ República. $2^{\mathrm{a}}$ ed. rev. Rio de Janeiro: Topbooks, 2002. 430 p.

QUEIROZ, Marcos Vinícius Lustosa. Constitucionalismo Brasileiro e o Atlântico Negro: a experiência constitucional de 1823 diante da Revolução Haitiana. Brasília. 2017. 200p. Dissertação (Mestrado em Direito, Estado e Constituição) - Programa de Pós-Graduação em Direito da Universidade de Brasília.

Série Inclusão: a conquista do voto feminino no Brasil. Disponível em $<$ http://www.tse.jus.br/imprensa/noticias-tse/2013/Abril/serie-inclusao-aconquista-do-voto-feminino-no-brasil>. Acesso em 30 de outubro de 2017.

Série Inclusão: a luta dos analfabetos para garantir seu direito ao voto na República. Disponível em <http://www.tse.jus.br/imprensa/noticiastse/2013/Abril/serie-inclusao-a-luta-dos-analfabetos-para-garantir-seu-direitoao-voto-na-republica>. Acesso em 27 de outubro de 2017. 
SILVA, José Afonso da. Curso de Direito Constitucional Positivo. $37^{\mathrm{a}}$ ed rev. e atual. São Paulo: Malheiros, 2013. 934p.

SOIHET, Rachel. A pedagogia da conquista do espaço público pelas mulheres e a militância feminista de Bertha Lutz. Disponível em < http://www.scielo.br/pdf/rbedu/n15/n15a07>. Acesso em 27 de outubro de 2017.

SMINK, Veronica. 5 precursoras del voto femenino en América Latina. Disponível

em $<$ http://www.bbc.com/mundo/noticias/2013/10/131018_100_mujeres_bastione s_feminismo_vs $>$. Acesso em 14 de outubro de 2017.

TRUTH, Sojourner. E não sou uma mulher?. Tradução de Osmundo Pinho. Disponível em < https://www.geledes.org.br/e-nao-sou-uma-mulhersojourner-truth/>. Acesso em 4 de novembro de 2017.

VÉLEZ, Gloria Estela Bonilla. La Lucha de Las Mujeres en América Latina: Feminismo, ciudadanía y derechos. Revista Palobra," palabra que obra", v. 8, n. 8, p. 42-59, 2015.

VILLAMÉA, Luiza. Olympe de Gouges, a pioneira do feminismo que foi parar na guilhotina. Disponível em $<\mathrm{https}$ ://www.geledes.org.br/pioneira-dofeminismo-que-foi-parar-na-guilhotina/ $>$. Acesso em 3 de novembro de 2017. 